\title{
LA RELACIÓN SOBRE LAS COSTUMBRES Y POBLADOS DE LOS MOCOVÍES Y ABIPONES TUTELADOS POR JESUITAS, ESCRITA EN EL EXILIO POR EL PADRE ANTONIO JOSÉ BUSTILLO
}

\author{
The relationship on the customs and villages of the Mocovies and abipones \\ supervised by Jesuits, written in exile by Fr. Antonio José Bustillo
}

\author{
Carlos A. Page* \\ https://orcid.org/0000-0003-4708-5243
}

\begin{abstract}
Resumen
E1 P. Antonio Bustillo no fue ni es, un jesuita muy conocido, pues no tuvo demasiada participación en la Provincia Jesuítica del Paraguay. Apenas llegó, concluyó sus estudios en Córdoba y recién se le asignó una ocupación a fines de 1764. Su destino fueron las misiones del Chaco, interiorizándose de aquellas etnias y en donde permaneció escasos dos años y medio. Suficientes, no solo para aprender la difícil lengua mocoví (moqoit), sino también para cofundar el pueblo de San Pedro, bajo el ala del P. Florián Paucke, justamente uno de los más famosos jesuitas de la historia de la provincia. El texto que aquí presentamos, no tuvo como fin ser publicado, sino que fue parte de los recolectados por el P. Lorenzo Casado para nutrir la obra que el P. Pedro de Calatayud pretendía escribir sobre la historia del Paraguay.
\end{abstract}

$<$ Antonio Bustillo $><$ Mocovís $><$ Abipones $><$ Exilio $><$ Pedro de Calatayud $>$

\begin{abstract}
Father Antonio Bustillo was not and is not a well-known Jesuit, because he did not have much participation in the Jesuit Province of Paraguay. As soon as he arrived, he finished his studies in Córdoba and was just assigned an occupation at the end of 1764. His destiny was the Chaco missions, being in contact with those ethnic groups, and where he spent only two and a half years. Time enough not only to learn the difficult Mocoví (Moqoit) language, but also to co-found the town of San Pedro, under the wing of Fr. Florián Paucke, one of the most famous Jesuits in the history of the province. The text presented here was not meant to be published, but was part of those collected by Father Lorenzo Casado to nurture the work that Father Pedro de Calatayud intended to write about the history of Paraguay.
\end{abstract}

$<$ Antonio Bustillo $><$ Mocovíes $><$ Abipones $><$ Exile $><$ Pedro de Calatayud $>$

Recibido: $25 / 11 / 2019$

Aceptado: 10/2/2020

\footnotetext{
* Doctor en Historia. Investigador Independiente CONICET. Centro de Investigaciones y Estudios en Cultura y Sociedad. Unidad Ejecutora del CONICET asociada a la Universidad nacional de Córdoba capage1@hotmail.com
} 
Page. La relación sobre las costumbres y poblados de los mocovíes y abipones tutelados por jesuitas, escrita...

El P. Antonio, nació el 30 de julio de 1730 en la pequeña población de Aloños (Storni, 1980, p. 46), atravesada por el arroyo Junquera, ubicada en la jurisdicción del municipio de Villacarriendo, en la provincia y comunidad autónoma de Cantabria. Perteneciente al arzobispado de Burgos, se destaca en el pequeño pueblo la iglesia parroquial dedicada a San Fructuoso, ubicada junto a su plaza, que data del siglo XVII, y donde seguramente Antonio José fue bautizado. Actualmente, también llaman la atención en el poblado, de poco más de un centenar de habitantes, las casas de Gaspar Bustillo de la Concha, caballero de Santiago, con las armas de Bustillo y Ceballos, y otra con las armas de Ceballos-Velasco y Guazo-Bustillo. Pues la casa Bustillo se remonta al siglo XIV. Pero el propio P. Antonio aclara, en el documento que presentamos a continuación, que él era natural del hayal de Aloño, es decir, el bosque de hayas que se encuentra en las inmediaciones.

En la mencionada parroquia de San Fructuoso, los Bustillo tenían su escudo de armas en la clave de la capilla de San Antonio de Padua, ubicada al lado del Evangelio, como así también su escudo en un banco de la misma iglesia (Escagedo Salmón, 1926, p. 132), lo que nos refiere la estirpe genealógica de Antonio.

Nada sabemos de sus padres y familiares directos, y de sus primeros años. Pero podemos afirmar que aproximadamente a los 21 años, Bustillo dejó su pueblo natal, al trasladarse al noviciado de Villagarcía del Campo, pues en la segunda mitad de 1751 ingresó a la Compañía de Jesús del Paraguay. Efectivamente, en el documento de embarque hacia América, se confirma, que había hecho su noviciado en Villagarcía, agregando que salió de allí, el 22 de mayo de 1753, rumbo al Puerto de Santa María, adonde llegó el 23 de diciembre de ese año, para embarcarse recién el 8 de abril de 1755, por lo que aguardó en el Hospicio de Misiones de los jesuitas por 16 largos meses.

Se sumó a la expedición de los procuradores del Paraguay, que fueron los PP. Pedro de Arroyo y Carlos Gervasoni, elegidos en la congregación de 1751. Pero ambos no regresaron al Paraguay, debido a que el primero falleció en Madrid el $1^{\circ}$ de abril de 1754. Mientras que el P. Gervasoni fue desterrado de España por su vehemente posición en contra del Tratado de Límites, radicándose en Génova, donde murió en 1773 (Page, 2007, p. 48).

El novicio Antonio se embarcó en el navío San Francisco Javier, alias "el torero", al mando del maestre Nicolás de Aizpurúa. Viajaron jesuitas para las misiones de Paraguay y sobre todo Chile, con su procurador el P. José Vera. Se registraron para el Paraguay 23 sacerdotes y estudiantes con 7 coadjutores, de un total de 60 religiosos que había concedido la corona para esta expedición, por real orden del 19 de febrero de 1754. Muchos de ellos serían luego muy conocidos por distintas circunstancias ${ }^{1}$. En la

\footnotetext{
1 Viajaron junto al por entonces estudiante Bustillo los PP. Mateo Cano, José Fischer, Bernardo Ibáñez de Echavarri y Juan Agustín Salis; los estudiantes José Chueca, Diego González, Simón Hernández, Alonso Hernández, José Jolís, Miguel Navas, Luis Olsina, José Manuel Peramás, Jaime Ignacio Oliver, Miguel Pardo, José Pellejà, Antonio Priego, Pedro Rodríguez, José Rufo, Ramón Salat, Luis Vázquez, Francisco Vila y Miguel Vilella, además de los HH. Gortardo Barenstainer, Juan Manuel Blanco, Pablo Castelló, Vicente Galiano, Blas Alberto Gorría, Wenseslao Horsky, Fernando Picavea, Juan Scheibner y Juan Wittgen (Pastells \& Mateos, 1949, pp. 207-209. Galán García, 1995, p. 337).
} 
mencionada reseña que se hizo de los que abordaron el barco, se escribió que Bustillo contaba con 24 años, que era "blanco, poca barba, ojos y pelo negros".

Arribaron al puerto de Montevideo el 17 de julio de 1755 (Storni, 1980, p. 46). A partir de su llegada a Buenos Aires, la información, no es más abundante, pues no es mencionado en la mayoría de la documentación conocida, encontrándose un periodo que va de 1755 a 1764 en el que no sabemos de su paradero². Pero especulamos que debió quedarse en Córdoba a estudiar Filosofía y Teología, teniendo quizás alguna función en aquella ciudad. Sí sabemos, y por el presente documento, que se ordenó sacerdote en Córdoba y ofreció su primera misa el 4 de diciembre de 1764. En ese mes y año fue enviado a la reducción de San Francisco Javier donde lo esperaba el P. Paucke. Desde entonces comenzó su tarea misional que tan solo duró menos de tres años.

En ese mismo año, pero apenas antes que arribara el P. Antonio, hizo su visita pastoral el obispo Manuel Antonio de la Torre quien recorrió San Francisco Javier, como dijimos, el destino del P. Antonio. También por noviembre pasó el provincial Pedro Juan Andreu, buen conocedor de la región chaqueña, quien regresó a Córdoba y envió al P. Antonio a aquel poblado, como lo hizo antes con los PP. Jolís y Gorostiza al Chaco. Llegó en la víspera de Navidad, siendo recibido con gran alegría por todos sus habitantes.

Poco después de su arribo, el 11 de enero, el mismo P. Antonio cuenta en el presente documento, que salieron con el P. Paucke, junto con unos mocovíes infieles y otros cristianos del cacique Elebodgín, a los fines de fundar un nuevo pueblo, previo a establecer una estancia de ganado vacuno para ellos, y que llegó a contar con más de cinco mil cabezas, además de ovejas y caballos. Finalmente encontraron un sitio adecuado, llamado Ispin-chico, y con la ayuda de 50 soldados al mando de Jerónimo Leyas y los indígenas, levantaron la capilla, habitación para los jesuitas con ladrillos y chozas para los indios, además de empalizar el poblado. El acto de fundación del pueblo que llamaron San Pedro, en honor al por entonces gobernador Cevallos, contó con todo el boato hispano, en una ceremonia encabezada por el teniente de gobernador Vera y Mujica quien dio posesión jurídica al P. Paucke y al cacique Elobodgín, arrancando hierba y tirándola al aire. El acto pareciera que fue el $1^{\circ}$ de mayo de 1765 . El provincial designó para este nuevo pueblo a los PP. Bustillo y José Lehmann, este último después pasó a San Jerónimo.

Comenzaron con las actividades propias de la reducción, centrada en la enseñanza del catecismo y los quehaceres que imponía el poblado. Por estos pasajes del relato, el P. Bustillo menciona los tres caciques bautizados y su gente, además de la actividad diaria y algunos ejemplos. También resalta las donaciones que dieron los habitantes y el colegio jesuítico de Santa Fe y los mismos indígenas de San Francisco Javier, con lo que pudieron sustentarse en los primeros meses.

Con la llegada de la expulsión se encontraban en el pueblo de San Pedro los PP. Bustillo y Pedro Poule, que fueron reemplazados por el sacerdote Francisco Reyes,

${ }^{2}$ Los Catálogos del ARSI, no llegan hasta esas fechas. 
Page. La relación sobre las costumbres y poblados de los mocovíes y abipones tutelados por jesuitas, escrita...

quien tuvo que hacerse cargo de un centenar y medio de habitantes. Escribe Paucke (2010, p. 472) que llevó una viuda de cocinera y sus dos hijos, como lo había hecho su reemplazante Miguel Ziburru en San Javier. Mientras tanto los jesuitas PP. Navalón, Lehmann, Paucke, Termeyer, Poule y Bustillo, fueron reunidos en San Francisco Javier y el 2 de setiembre partieron todos juntos a Buenos Aires con el comisionado Pedro Miura y en compañía del cacique Nevedagnac y sus súbditos. Llegaron a la ciudad de Santa Fe el día 5, sin entrar en ella y de allí a la estancia jesuítica de Santo Tomé (o San Miguel para Paucke), donde tampoco se les permitió ingresar. Allí se les sumó el P. Juan Francisco Ortiz de Ocampo y el H. Miguel Martínez. El 8 se despidieron de los indios y partieron rumbo a Tres Arroyos con el nuevo comisario que se incorporó, un tal Piedra Buena. De allí, este último fue reemplazado por el capitán Benítez que los acompañó hasta la Casa de Ejercicios del colegio de Belén, en Buenos Aires, que estaba fuertemente guarnecido por soldados. Permanecieron en la casa hasta el 10 de marzo (10 de abril para Paucke) de 1768 en que 72 jesuitas cruzaron el Río de la Plata para abordar la fragata de guerra "La Esmeralda", a cargo del capitán de fragata Mateo Collado. Se sumaron a un centenar, que ya estaban a bordo, donde también viajó el gobernador de las islas Malvinas, el francés Michel-François Bougainville de Nerville, después que las entregó a los españoles.

En la fragata Esmeralda viajaron jesuitas del colegio de Asunción con su rector el P. Antonio Gutiérrez, también de las misiones de mbayas, guanaes y taumas, donde estaba el P. Sánchez Labrador, del colegio de Corrientes con su rector el P. Juan Antonio García, de la residencia de Catamarca, algunos de los colegios de La Rioja, Tarija, Tucumán, Potosí, Santiago del Estero, Salta, San Juan, Buenos Aires, Santa Fe, Chile y Córdoba. De las misiones del Chaco, estaban todos, incluso el P. Bustillo ${ }^{3}$. En el viaje fallecieron dos coadjutores, el boliviano Manuel Guzmán y el alemán Tomás Heyrle que contaba con 70 años.

Recién levaron anclas el 6 de mayo, arribando a Cádiz el 22 de agosto, siendo trasladados al Puerto de Santa María y ubicados en el Hospicio de Misiones, donde se habían alojado primero los jesuitas españoles y luego el primer contingente que salió del Río de la Plata y ya estaban rumbo a su destino final en los estados pontificios. Allí quedarían bajo la responsabilidad del marqués de la Cañada Terry.

El P. Paucke junto con otros extranjeros se separó del resto y partieron de España el 29 de marzo de 1769. La mayoría de los que quedaron viajaron directamente a Italia, sin sufrir los padecimientos de la expedición anterior que pasó por Córcega, relatada por el P. Peramás, habiéndose quedado algunos enfermos que murieron finalmente en el Puerto de Santa María en número de 20, entre los que se encontraba el provincial Vergara.

Aclaremos que los jesuitas americanos partieron a Italia en tres expediciones, en los años 1768, 1769 y 1770. Bustillo lo hizo en la segunda, ya que llegó después que zarpara el primer convoy con 1.051 jesuitas de ultramar, entre el 10 y el 14 de junio de 1768 (Pacheco Abate, 2007, p. 205). La segunda tanda eran unos 500 jesuitas repartidos

Biblioteca Nacional de España, Ms 12870, f. 39 y Pastells Mateos, 1949, t. 8b, p. 1301. 
en dos navíos: El Grolen y La Esperanza que salieron en febrero de 1769, aunque aún quedaban unos 200 en el Puerto.

Ya en Italia y al poco tiempo de su llegada a Brisighella, profesó su cuarto voto el 15 de agosto de 1769 (Storni, 1980, p. 46). Nos resulta difícil rastrear los 27 años posteriores que soportó en el exilio, hasta su muerte, ocurrida en Faenza el 9 de diciembre de 1796. Sabemos que la mayoría de los jesuitas del Paraguay fueron a Faenza, donde continuaron con los estudios, algunos pocos se ubicaron en Ravena y los menos en Ímola y Brisighella, ubicada esta última a poco más de $12 \mathrm{~km}$ de Faenza, donde se concentraron en dos casas. Ubicamos allí, pero por un tiempo, a José Jolís y Roque Gorostiza, aunque ambos murieron, uno en Bolonia y el otro en Roma ${ }^{4}$, mientras varios otros fallecieron en Brisighella. También es importante mencionar que José Guevara fue rector del colegio de Brisighella, entre 1769 y 1772 (Storni, 2001, p. 1837). Un dato importante es que Joaquín Camaño, en carta firmada en Faenza, el 15 de junio de 1783, le recomendó a Hervás para que Bustillo, que se encontraba en la pequeña villa de Castel Bolognese en Ravena, haga una gramática en lengua mocoví en base a una de Camaño; pero no consiguió hacerla (Piciulo, 2014, p. 789).

Así transcurrió la vida del P. Bustillo, de la que no poseemos mayor información. Sin duda tuvo una buena relación con el P. Lorenzo Casado, quien fue el que mayor ayuda le prestó al P. Pedro de Calatayud, con su intención de escribir la historia del Paraguay, y lo contactó con varios jesuitas para que escribieran sus experiencias en la región, como los PP. Quiroga, Guevara, Valdés, Castro, Burgés, Arto, Fabra, García y por supuesto Bustillo, cuyos relatos formaron un grueso legajo que se encuentra en el Archivo Histórico del Santuario de Loyola, que paulatinamente estamos dando a conocer en forma completa (Page, 2019a, 2019b, 2019c).

Este legajo lo conoció el P. Furlong en su viaje por los archivos europeos en 1924, y junto con otro que encontró en Barcelona (hoy en Alcalá de Henares), formó la serie sobre otras reducciones que los antiguos jesuitas levantaron en el Paraguay, aparte de las de guaranís, es decir, entre los pampas, mocovíes, vilelas, lules, tobas y mataguayos, abipones y tehuelches; quedando inéditos y hoy perdidas sus obras sobre los calchaquíes y los tobas (Geoghegan, 1974, p. 492). Furlong no escribió sobre el P. Bustillo, como lo hizo con muchos otros, aunque señaló que "fue uno de los misioneros que más trabajaron en las reducciones de aquellos indios" (Furlong, 1938, p. 7).

Sobre los mocovíes, los jesuitas del exilio dejaron varias relaciones. La más importante es la del P. Paucke, aunque no específica, pero fue el gran protagonista, como lo fue Dobrizhoffer entre los abipones. A veces no solo escribieron una relación, sino dos, como el P. Burgés, una se encuentra en el archivo de Alcalá, publicada (Maeder et al, 2016, pp. 283-302) y otra en el de Loyola, inédita. También escribieron sobre los mocovíes el P. Manuel Canelas (Maeder et al, 2016, pp. 303-378), extenso y detallado texto, comentado por Salinas y Valenzuela (2015), que incluso hacen un recuento de la historiografía de la etnia en particular y análisis de este tipo de fuentes jesuíticas, que compartimos.

\footnotetext{
${ }^{4}$ Archivo Histórico Nacional, Madrid: Clero-Jesuitas 223,2 224,6 225,5.
} 
Page. La relación sobre las costumbres y poblados de los mocovíes y abipones tutelados por jesuitas, escrita...

La relación del P. Bustillo no fue escrita para ser impresa, como las mencionadas del Archivo de Loyola. Ni siquiera las publicadas por Maeder (2016) que fueron encargadas por el P. Camaño para nutrirse de información para su proyecto de enciclopedia étnica. Son textos que podríamos llamar de circulación interna entre los expulsos, que no le otorgan un sentido propagandístico, y ni siquiera apologético, válido para otras producciones literarias, desde Del Techo a Muriel, pasando por Lozano. Estos textos son diferentes, no solo en el gran cambio producido en la literatura dieciochesca, sino también por el contexto del exilio. Los jesuitas relataron sus vivencias con una lógica visión eurocéntrica sobre el hombre americano, con la frescura del recuerdo de su propio pasado, con sus éxitos y penurias, pues en la mayoría de los casos cayeron en autobiografias, sin intereses personales.

Bustillo comienza destacando la guerra que por más de una década entablaron los mocovíes y abipones, hasta que con la intervención de las autoridades españolas se logró pacificar la región y crear las reducciones, primero de San Francisco Javier de mocovíes (1743) bajo el manto del P. Francisco Burgés, quien aprendió y trasmitió la difícil lengua a sus compañeros los PP. Canelas, Brigniel y Paucke, entre otros. Posteriormente se fundó el pueblo de San Jerónimo de abipones (1748) a cargo del P. Diego Horbegoso y su compañero Francisco Navalon, quien había sido antes compañero del P. Burgés en San Javier, aunque también fueron de la partida fundacional los PP. Cardiel y Brigniel.

El texto de Bustillo menciona los principales caciques de ambas naciones que, incluso conoció, y que se habían comprometido en la defensa de las ciudades españolas frente a rebeldes, como Huarcaiquin quien se enfrentó a los caciques reducidos, con todos los condimentos de la guerra: con sus traiciones y muertes. Finalizadas estas contiendas se ampliaron las reducciones abiponas, creándose las de Nuestra Señora de la Concepción, en la jurisdicción de Santiago del Estero, San Fernando en la de Corrientes y Nuestra Señora del Rosario en la de Asunción, aunque con no poca sangre corrida por las tierras indígenas.

Bustillo hace una digresión al mencionar la muerte del joven jesuita Santiago Herrero, del que escribimos en su momento (Page, 2011, pp. 41-71 y 2018a, pp. 21-51) aunque no contamos con algunos datos aquí consignados. Para los jesuitas de su tiempo, la muerte del P. Herrero fue de un gran impacto, pues varios expulsos lo recordaron, como Casado, Paucke y Dobrizhoffer, entre otros.

El relato continúa con las acciones que emprendió el P. Bustillo junto al P. Paucke, entre ellas y como mencionamos, la de concretar una hacienda para el nuevo pueblo de San Pedro, describiendo los parajes por donde anduvieron, deteniéndose extensamente en la fauna y flora de la región, incluso por ejemplo, en la utilización de las palmeras, como tejas para los edificios, o el lapacho para la construcción de carretas. También describe la morada que tenían ambos, pasando luego a relatar la actividad diaria en el poblado. Son interesantes también los nombres que aporta de los caciques, algunos conocidos en la historiografía tradicional y otros no. No deja de relatar los recurrentes y típicos casos particulares de estos textos, como describir tareas que los mismos jesuitas 
hacían con los indios, desde la agricultura a la carpintería y cómo eran esas labores, desempeñándose incluso hasta como médicos. Hace referencia a la dieta y cómo se distribuían los alimentos y herramientas. Gran parte de las provisiones que consumían venían de los pobladores y del colegio de los jesuitas de Santa Fe que provenían de los diezmos. Describe la religiosidad mocoví, su armamento y estrategias de combate, su vestimenta, la conformación familiar, sus hechiceros, la difícil lengua, tanto la abipona, como la mocoví, que incluso se diferenciaba entre los "nobles y caciques de la de los plebeyos", como también entre hombres y mujeres.

Puntualiza a los mocovíes en su contextura física, resaltando la curiosidad que entre ellos había rubios, seguramente de españoles que fueron a vivir con ellos, libre o compulsivamente. Concluye con un somero relato de los días de la expulsión y la reacción de los indios, agregando finalmente un ligero inventario, de los tres pueblos, del ganado y cultivos, población, edificaciones y sus materiales, los ornamentos de las capillas y también sus deudas al Oficio de Misiones de Santa Fe. En síntesis, el texto del P. Bustillo contribuye a la elaboración de un corpus documental sobre una de las numerosas naciones que poblaron el Chaco y que los españoles en definitiva no pudieron agregar a sus dominios, aunque lo incorporaran a su cartografía.

[1] (con otra letra: Relacion del Padre Antoni $i^{\circ}$ Bustillo. Missionero y fundador de este pueblo) ${ }^{5}$

Relacion sucinta de la fundacion de los tres Pueblos de $\mathrm{S}^{\mathrm{n}}$ Francis ${ }^{\mathrm{co}}$ Xavier, y $\mathbf{S} a^{\mathrm{n}}$ Pedro de la nacion Mocobi, y $\mathbf{S a}^{\text {n }}$ Geronimo de la Abipona, de sus hostilidades contra los españoles, de algunas de sus costumbres, numero de ellos, y de su estado en lo temporal, y espiritual al tiempo del destierro de los Padres Jesuitas de todos los Dominios de Nuestr ${ }^{0}$ Catolico monarca el Señ ${ }^{\text {or }}$ Carlos Tercero, que Dios guarde, y del modo de haverse en el con los dichos PPadres los comissionados con otras varias cosas.

La nacion Mocobi, terror por sus hostilidades en los españoles, y por dilatados años, de las tres Provinci $i^{\text {as }}$ en lo militar, y politico: Paraguay, Rio de la Plata, y Tucumán, no es numerosa, pues sus individuos de uno, y otro sexo, entre grandes, y pequeños, no pasan de dos mil, y ducientos. Algo menos numerosa es la nacion Abipona, Toba, Vilela, y Malvalae, en cuya compañia alborotaron, con mas obstinación, efusion de sangre española, y perdida notable de sus haciendas, desde el año de 1733, ó 34 hasta el de $1748^{6}$ en que se fundó el Pueblo de $\mathrm{S} a^{\mathrm{n}}$ Geronimo de la Nacion Abipona, y aun hasta [1v] el de 1765 en que se formó el Pueblo de $\mathrm{S} a^{\mathrm{n}}$ Pedro, el segundo de la Nacion

5 Archivo Histórico del Santuario de Loyola, Misiones, Paraguay, Documentos históricos 15701770. Caja 19/1, Legajo 5.

${ }^{6}$ El teniente de gobernador de Santa Fe don Francisco Javier de Echagüe y Andía logró concertar la paz con el cacique Ariacaiquín en 1734 y ofrecer misioneros para que se redujeran. Pero diversas circunstancias postergaron la concreción de la reducción por nueve años, hasta que se efectivizó lo estipulado en julio de 1743. Mientras tanto varios grupos aborígenes con sus familias se establecieron en los alrededores de Santa Fe, dedicándose al comercio con los vecinos de la ciudad de Garay, mientras otros tantos frecuentaban el colegio jesuítico (Page, 2012, p. 306). 
Page. La relación sobre las costumbres y poblados de los mocovíes y abipones tutelados por jesuitas, escrita...

Mocobi, y el primero de este nombre entre todos los que fundó la Compañía de Jhesus en su, en otro tiempo, Provincia del Paraguay, pero ya con poco daño, y con larga intervencion las Ciudades de $\mathrm{S} a n^{\text {ta }}$ Fee de Vera Cruz, la de las Siete Corrientes, ó $\mathrm{S} a^{\mathrm{n}}$ Juan de Vera en el gobierno de Buenos Ayres, y sus estendidissimas jurisdicciones, con parte de las florecientes Missiones de Guaranis, y la mayor parte de la dilatadissima jurisdiccion de la Ciudad de Assumpcion, Capital del Paraguay, y las Ciudades de Cordoba, Santiago del estero, $\mathrm{S} a^{\mathrm{n}}$ Miguel de Tucumán, Salta, ó $\mathrm{S} a^{\mathrm{n}}$ Phelipe de Lerma, y $\mathrm{S} a^{\mathrm{n}}$ Salvador de Jujui, en la Provincia también del Tucumán, haciendo impracticables para todo comercio entre si sus caminos, y cerrandolos totalmente para el transporte mutuo entre ellas, el Perú, y Chile. Paso á tanto su intolerancia que en la Ciudad de $\mathrm{S}{ }^{\text {ta }}$ Fee de Vera Cruz con poca reserva se passeaban por sus calles, obligando á sus moradores á no poder salir á ello sin las armas en la mano, y á no dexarlas aun para oir missa: y en las demás encerrandolos de tal suerte que no salian de ellas aun prevenidos de armas sin peligro manifiesto de la vida. Llegaron últimamente los vecinos de dicha Ciudad por la falta de viveres, continuos, y por vigorosos arrebatos de los infieles al forzoso estado de guerra ya desampararla. Acudio en este aprieto la Compañía de Jhesus, embiando por el Rio Paraná de la hacienda del mismo Colegio de San ${ }^{\text {ta }}$ Fee de Vera Cruz nombrada $\mathrm{S} a^{\mathrm{n}}$ Miguel $^{7}$, en abundancia bastimento á la Ciudad, y el $\mathrm{S} e \tilde{n}^{\text {or }} \mathrm{D} o^{\mathrm{n}}$ Francis ${ }^{\mathrm{co}}$ Xavier de Echague ${ }^{8}$, y otro theniente de Governador, Justicia Mayor, y capitan de guerra, con su extraordinario valor, é industria peculiar de el manejo de las armas contra tales enemigos, á defender qual nunca su patria, obligando á los barbaros por el miedo á contenerse, y a que por el mismo lo respetasen y amassen por su trato benevolo, y cortés con ellos. Con estas dos fuertes armas del valor, y humanidad consiguieron [2] al cabo de tiempo dexassen por concierto de paz descansar unica entre todas las demás á su Ciudad de San ${ }^{\text {ta }}$ Fee de Vera Cruz, y haverse con ella amigablemente las dos marciales, é indomitas naciones, Mocobi, y Abipona. Pero no teniendo como practico este loable capitán por solidas aquel, las paces, y segura á su Ciudad de toda irruccion enemiga, sino se ratificaban con los establecimientos en Pueblos de estas dos referidas naciones, sugetas á vida christiana, y política, habló sobre este punto zeloso á los Caciques, prometiendoles Missioneros á su arbitrio, y haciendoles otras promessas,

\footnotetext{
${ }^{7}$ La estancia de San Miguel del Carcarañá la adquirieron los jesuitas en 1719, con todos sus ganados, al por entonces maestre de campo Antonio de Vera Mujica. Era una gran extensión donde hoy se encuentran las poblaciones de San Lorenzo, San Martín, Bella Vista y Jesús María. El casco de la estancia estaba en el sitio de San Miguel y tenía adosada una capilla con espadaña, cubierta de tejas. Casi siempre estuvieron allí dos jesuitas, siendo el primero el P. Sebastián Garau quien estuvo al frente durante 13 años. También estuvieron Tomás Falkner, por cuatro años, tiempo en el que hizo excavaciones que lo condujeron a descubrir un gliptodonte. Lo sucedió como mayordomo el H. Carlos María Pirola (Furlong, 1962, I, pp. 379-393).

${ }^{8}$ Echagüe y Andía nació en Santa Fe el $1^{\circ}$ de setiembre de 1693, siendo sus padres el general Francisco Pascual y doña María Márquez Montiel. Estudió con los jesuitas de su ciudad natal y luego se dedicó a las armas, anotándose en casi todas las salidas que se hicieron en defensa de la ciudad. Asumió como teniente de gobernador en 1733 hasta su muerte, ocurrida en Santa Fe el 2 de octubre de 1743, no llegando a ver concretada la primera reducción de mocovíes (Page, 2012, p. 306)
} 
capaces á rendir animos no tan sujetos á brutales apetitos. En este tiempo los Jesuitas del Paraguay como siempre solicitos de la propagacion de la fee, servicio de su Monarca, y tranquilidad de la republica, hicieron también de su parte para fundar, y fundaron por el mes de Julio de 1743 con algunos Mocobis menos protervos, y mas dóciles, á costa de innumerabes trabajos el Pueblo de $\mathrm{S} a^{\mathrm{n}}$ Fran $c i{ }^{\mathrm{co}}$ Xavier, oy floreciente, de la nacion Mocobi, coadiuvando eficazmente á los catolicos intentos del sobredicho Señor teniente $\mathrm{D} o^{\mathrm{n}}$ Francis ${ }^{\mathrm{co}}$ Xavier de Echague, y Andia.

Arropose con su notorio zelo el primero á esta empresa, esforzado empero con el espiritu de su Padr ${ }^{\mathrm{e}}$ Vic ${ }^{\mathrm{e}}$ Provincia ${ }^{1}$ Pedro de Arroyo ${ }^{9}$, hijo de Madrid, y con el del $\mathrm{P} a d r^{\mathrm{e}}$ Rect ${ }^{\text {or }}$ del Colegio de San ${ }^{\text {ta }}$ Fee de Vera Cruz Miguel de $\mathrm{Cea}^{10}$, de Carmona en Andalucia, su superior immediato, el Padre Francis ${ }^{\mathrm{co}}$ Burgés ${ }^{11}$, de Pamplona, metiéndose entre los infieles sin defensa alguna humana, y falto totalmente de la inteligencia de su dificilicimo idioma, y de todo precepto para conseguirla, como lo estaban tambien los demas Jesuitas de la Provincia, y los españoles todos menos tal qual que cautivo algunos años havia vivido entre ellos. Aplicose tanto este fervoroso Missionero á aprender su lengua, fundamentarlos en las maximas de nuestra santa fee, purgarlos, de sus vicios, y barbaras costumbres, á aumentar su [2v] numero, reduciendo otros, y á establecerlos en Pueblo en sitio saludable, y a proposito para vna poblacion deliciosa de indios y aun de españoles, que á los nueve años de este su ministerio, se halló con mas de mediana pericia en la lengua Mocobi, y dexó á sus sucessores algunos apuntes de ella, para qu con menor dificultad la entendiessen, y hablassen, y al Pueblo con muchas almas, y tan instruidas que las mas, ó casi todas, eran ya christianas, y muchas casadas in facie ecclasiae, y en el lugar fértil, en que oy se halla despues de tres fundaciones llamado en

9 El P. Pedro Arroyo (Madrid, 1689-1754), ingresó a la Compañía de Jesús de la provincia de Toledo en 1704. Dos años después profesó sus primeros votos y llegó a Buenos Aires en 1712 en la expedición del P. Francisco Burgés. Estudió en Córdoba y profesó su cuarto voto en 1722. Fue provincial algunos meses de 1743, luego de haber sido elegido procurador a Europa en 1740, sin poder viajar. Nuevamente fue electo procurador y viajó con el P. Gervasoni pero falleció en España (Storni, 1980, p. 23). A su vez fue profesor de Filosofía, Teología Moral y Derecho Canónico, siendo también rector de los colegios de La Rioja, Buenos Aires y Córdoba (Furlong, 1944, I, pp. 287-288).

${ }^{10}$ El P. Cea nació en Carmona, Sevilla, el 9 de agosto de 1694, ingresando en la provincia jesuítica de Andalucía en 1712 y dando sus últimos votos en Sevilla en 1724. Llegó a Buenos Aires en 1729, junto al P. Bonenti, falleciendo en las misiones guaraníticas en 1768, antes de ser trasladado al exilio (Storni, 1980, p. 62). Fue rector del colegio de Santa Fe y procurador de abipones y mocovíes (Furlong, 1938a, p. 179).

${ }^{11}$ El P. Burgés nació en Pamploa el 2 de febrero de 1709, siendo hijo de Nicolás y María Antonia Amunarriz y Navarro. Ingresó a la Compañía de Jesús en la provincia de Castilla en 1728 y al año siguiente llegó a Buenos Aires en la expedición del P. Jerónimo Herrán. Terminó sus estudios en Córdoba, obteniendo el sacerdocio en 1738 y dando sus últimos votos en Santa Fe en 1747. Estuvo entre los mocovíes por 19 años hasta que se le nombró procurador del colegio de Santa Fe. Luego de 1763 pasó a los mbayás con el P. José Mas. Se encontraba en el colegio de Asunción para tiempos de la expulsión, muriendo en Faenza el 28 de diciembre de 1777 (Storni, 1980, p. 45, Furlong, 1938a, p. 21). Cuatro años antes que el P. Burgés llegara a Buenos Aires había fallecido un homónimo de gran trayectoria que alcanzó a ser provincial en Chile (1695- 1699) y procurador del Paraguay en Europa (1703-1712) (Storni, 1980, p. 45). 
Page. La relación sobre las costumbres y poblados de los mocovíes y abipones tutelados por jesuitas, escrita...

lengua Mocobi Cazomogót, en la española de las barrancas, sobre el rio dulce á la costa del Paraná, y distante de la Ciudad de $S a n^{\text {ta }}$ Fee de Vera Cruz quarenta leguas á su norte algo inclinado al Oriente.

Prosiguieron sucesivamente con igual zelo este ministerio hasta nuestro destierro los Padres Manuel Canelas ${ }^{12}$, de Cordoba del Tucuman, que singularmente aprendio el lenguage Mocobi, Joseph Brigniel ${ }^{13}$, de Clangenfurt en la Alemania, que con su mucha aplicacion, y facilidad en aprender lenguas extrañas, y barbaras, se hizo capaz tambien de la Mocobi, y Abipona, Florian Paucke ${ }^{14}$, de Vincig en Silesia Prusia, y en qualidad de sus compañeros otros muchos zelosos Jesuitas.

Con esta fortaleza sintió la Ciu $d a^{\mathrm{d}}$ de San ${ }^{\text {ta }}$ Fee de Vera Cruz algunos efectos de la convenida paz y se estendieron algun tanto sus moradores, aunque siempre con el zelo, por su jurisdiccion, atendiendo al cultivo de los campos y establecimientos de haciendas de ganado bacuno, y ovejuno y con mayor cuidado al de mulas, y caballos por la mayor utilidad. En este tiempo el Pueblo de $\mathrm{S} a^{\mathrm{n}}$ Xavier, pequeño por el corto numero de sus habitantes, no se vio libre de los insultos de los Abipones, y barbaros Mocobis, aun no sujetos, que llevando muy á mal aquel perpetuo estorvo para sus correrias, y atrocidades, contra los españoles, acometieron al mismo Pueblo varias veces, y á sus haciendas, haciendo [3] por la superioridad en el numero alguna otra muerte en sus

${ }^{12}$ El P. Canelas nació en Córdoba (Argentina) el 24 de abril de 1748, ingresando a la Compañía de Jesús cuando rondaba los 21 años. Alcanzó el sacerdocio a fines de 1743 y sus últimos votos los profesó en Santa Fe en 1752. La expulsión lo sorprendió en el Colegio de Córdoba, muriendo en Faenza el 22 de marzo de 1773 (Storni, 1980, p. 50). Estudió en el Colegio Máximo de Córdoba donde fue maestro de gramática al igual que en Santa Fe. Estuvo entre los mocovíes desde principios de 1749, escribiendo en el exilio una relación sobre ellos que se encuentra en el archivo central de la Compañía de Jesús en Alcalá de Henares. Documento que trabajó tanto Furlong (1938a), como Salinas y Valenzuela (2015).

${ }^{13}$ El P. Brigniel nació en Klagenfurt, Austria, el 24 de marzo de 1699, ingresando en la provincia austriaca en 1716. Llegó a Buenos Aires en la expedición del P. Jerónimo Herrán de 1729. Profesó sus últimos votos en el pueblo guaraní de Candelaria en 1733, estando en varias reducciones, siendo rector del colegio de Corrientes (1743-1747) en reemplazo del P. Matías Strobel, luego comisario del Santo Oficio y rector del colegio de Santa Fe (1762-1765). Pasó de San Jerónimo a Rosario del Timbó de abipones, donde lo sorprendió la expulsión. En Europa estuvo un tiempo en Italia sin pensión, volviendo a su patria, donde murió en Wiener en 1773 (Storni, 1980, pp. 43-44 y Furlong, 1938b, p. 109).

${ }^{14}$ El P. Paucke es uno de los antiguos jesuitas más conocidos de la provincia del Paraguay. Nació en Winzig (en polaco, Wińsko), en la provincia de Baja Silesia, Polonia, el 24 de septiembre de 1719. Ingresó a la Compañía de Jesús de Bohemia en 1736, estudiando en Praga, Wroclaw y Olomouc. Luego se ordenó sacerdote en 1748 y viajó al Río de la Plata, arribando a Buenos Aires en la expedición del P. Ladislao Orosz de 1749. Completó sus estudios en Córdoba, de donde fue enviado a la reducción de San Javier de mocovíes en 1752, para luego profesar su cuarto voto en el colegio de Santa Fe en 1754. Consolidada aquella reducción, el P. Paucke comenzó la de San Pedro, que debió ser abandonada por la expulsión, que lo sorprendió en la reducción de San Javier, partiendo al exilio y luego a su patria, muriendo en Neuhaus (en checo, Jindřichův Hradec), Bohemia, el 14 de julio de 1779. Su obra "Hacia allá y para acá" la escribió durante sus últimos seis años de vida, constituyéndose en una verdadera enciclopedia ilustrada sobre la vida y costumbres de los mocovíes, publicada en varias oportunidades, total o parcialmente (Storni, 1980, p. 215. Baptista, 2001, p. 3.451. Furlong, 1972). 
habitantes, y llevandose consigo todas sus bacas, y caballos. Aumentado notablemente de dia en dia el mumero de cathecumenos, y Neofitos del referido Pueblo de $\mathrm{S} a^{\mathrm{n}}$ Xavier con los Mocobis infieles, que á el de nuevo se agregaban, se fue haciendo temer de los barbaros aun no reducidos, y experimentó menos irruciones ya de ellos, y les impidio con mas fortaleza el passo para la Ciudad de San ${ }^{\text {ta }}$ Fee de Vera Cruz, y su jurisdiccion.

Entre tanto las tras Ciudades sobredichas de los tres gobiernos: Paraguay, Rio de la Plata, y Tucuman, y las indómitas naciones de Mocobis, y Abipones, continuaban de dia en dia con mas crueldad las hostilidades sin medio por parte de los españoles para ocurrir á tan graves males. Implorada con oraciones, y suplicas, la Divina Clemencia, y por ellas satisfecha su infinita Justicia, se logró ultimamente, havida con las armas alguna otra ventaja sobre los Indios, en que quedaron algunos muertos, y no pocos cautivos, y no interrumpidas diligencias de los Jesuitas, la paz general tan deseada entre todas las Ciudades, y sus jurisdicciones de las mencionadas Provincias: Paraguay, Rio de la Plata, y Tucumán, y los invencibles Mocobis, y Abipones, con la fundacion al mismo tiempo del Pueblo de $\mathrm{S} a^{\mathrm{n}}$ Geronimo de la Nacion Abipona en los términos de la jurisdiccion de la Ciudad de $\mathrm{San}^{\text {ta }}$ Fee de Vera Cruz, á la costa del Rio Paraná sobre el arroyo, llamado del Rey, y retirado de ella ochenta leguas al Norte. Celebraronse estas paces generales en año de 1748, y en el mismo por Octubre se establecio el sobredicho Pueblo de $\mathrm{S} a^{\mathrm{n}}$ Geronimo siendo Provincial del Paraguay el Padre Manuel Querini ${ }^{15}$, de Zante en el Archipielago, Rect ${ }^{\text {or }}$ del Colegio de Santa Fee de Vera Cruz, y Superior de aquellas nuevas Missiones el Padr ${ }^{\mathrm{e}}$ Diego de Horbegoso ${ }^{16}$, de Bilvao. Este fervorozo Jesuita, y vigilante Superior, no satisfecho con diligencias á expensas quantiosas de su Colegio nada opulento esta nueva fun-[3v]dacion, pospuestas todas las comodidades de el, y atropellados los peligros de su vida, salio para mexor facilitarla en compañia del Padre Francis ${ }^{\mathrm{co}}$ Navalon $^{17}$, compañero entonces en el Pueblo de S $a^{\mathrm{n}}$ Xavier del Padre Francis ${ }^{\mathrm{co}}$

${ }^{15}$ El P. Querini nació el 29 de mayo de 1694 en la isla de Zante, por entonces factoría veneciana, ingresando a la Compañía de Jesús en Roma en 1711. Llegó a Buenos Aires en la expedición del P. Jiménez en 1717 y tres años después le concedió el sacerdocio el obispo Pozo y Silva en Córdoba, donde en su universidad fue profesor y rector. Llegó a ser provincial (1747-1751), sorprendiéndolo la expulsión en Córdoba y falleciendo el Roma el 3 de mayo de 1776 (Storni, 1980, p. 229). Sendas biografías escribió primero, su contemporáneo Peramás (1946, pp. 93129) y luego Furlong (1967).

${ }^{16}$ El P. Horbegozo nació en Bilbao, el 15 de julio de 1697, ingresando en la Compañía de Jesús de Castilla en 1719. Llegó a Buenos Aires en la expedición del P. Jerónimo Herrán en 1729, lugar donde seis años después profesó sus últimos votos. Fue profesor y rector del colegio de Córdoba (1739-1744) y el de Santa Fe (1747-1751). Luego pasó de misionero a San Borja de los guaraníes y administrador de la estancia Las Vacas en Uruguay. La expulsión lo sorprendió en el puerto de Santa María en Cádiz, donde murió el 5 de setiembre de 1767 (Storni, 1980, p. 143 y Furlong, 1938b, p. 101).

${ }^{17}$ El P. Navalón, nació en Olmedo, Valladolid, el $1^{\circ}$ de marzo de 1716, ingresando a la Compañía de Jesús en 1732, llegando a Buenos Aires dos años después en la expedición del P. Antonio Machoni. En ese año profesó sus primeros votos y su sacerdocio lo cumplió en 1743. Estando en Santa Fe dio sus últimos votos en 1750, sorprendiéndolo la expulsión en la reducción de San Jerónimo. Fue llevado a Europa, muriendo en Faenza el 28 de enero de 1783 (Storni, 1980, p. 197). 
Page. La relación sobre las costumbres y poblados de los mocovíes y abipones tutelados por jesuitas, escrita...

Burgés, á buscar por el campo, y montes, á los Infieles Abipones, que encontrados á las ochenta leguas de viage en el sitio mismo que poco despues se formó el pretendido Pueblo de $\mathrm{S}^{\mathrm{n}}$ Geronimo y ganados con algunos obsequiosos donativos primero sus afectos, obligó con su persuasiva natural, acompañada de un espiritu Apostolico, a que algunos de ellos con sus dos Caciques Niripuri, y su sobrino Ichoalai ${ }^{18}$, que despues, y por los españoles, se llamó Joseph Benavides, conviniessen determinadamen ${ }^{\text {te }}$ en formarse en Pueblo, y escogieron luego para el el terreno, donde actualmente entonces se hallaban. Prometioles para mas cautivarles la voluntad dexar en su compañia en aquel sitio al Padre Francis ${ }^{\mathrm{co}}$ Navalon mientras su Reverenci ${ }^{\mathrm{a}}$, volviendo á la Ciu $d a^{\mathrm{d}}$ de $S a n^{\text {ta }}$ Fee de Vera Cruz, daba cuenta de lo obrado al Señ ${ }^{\text {or }}$ theniente, y, dispuestas las cosas, volvia dentro de pocos dias á verlos assistiendo personalmen ${ }^{\text {te }}$ á la ereccion de su apetecido Pueblo. Huvierasse executado assi, si los Blandengues, assi llamados á los Patricios, soldados de dicha Ciud $a^{\mathrm{d}}$ no se huvieran, poseidos del miedo á estos Indios, opuesto á quedarse entre ellos por algun tiempo aun en compañia del Padre Navalon, y en circunstancias de amistad. Por cuya repugnancia fue forzoso al Padre Diego tornarse con su compañero, pero con el consuelo por las promesas sinceras de los barbaros de encontrarlos á su vuelta en aquel mismo parage. Noticioso el Señor theniente $\mathrm{D} o^{\mathrm{n}}$ Francis ${ }^{\mathrm{co}}$ Antonio de Vera, y Muxica ${ }^{19}$ del estado, y animos de los Indios, se dispuso promptamente, anteponiendo el bien de la patria, el servicio de Dios, y del Rey, á todo descanso proprio, á erigir, y fomentar con su presencia, proceder ajustado y bienes proprios aquella nueva fundacion.

Salieron juntos de la Ciu $d a^{\mathrm{d}}$ de San ${ }^{\text {ta }}$ [4] Fee de Vera Cruz el sobredicho Señ ${ }^{\text {or }}$ theniente, y el Padre Rect ${ }^{\text {or }}$ ya mencionado Diego de Horbegoso, llevándose consigo

\footnotetext{
${ }^{18}$ Algunos autores, siguiendo a Paucke, afirman que Niripuri es Benavídez. Lo cierto que el único que lo menciona como tío de Yschoalay es el P. Bustillo. En tanto que Ychoalay, Ichoalay, Oahari (nombre de su juventud) ó José Antonio Benavides (nombre hispano que siguió el del P. Miguel Benavídez, rector del colegio de Santa Fe, que lo bautizó), fue un célebre cacique abipón del grupo de los Rükahés (ó Riikahés) ("gente del campo"), originario y habitante nómada del actual territorio nordeste de la provincia de Santa Fe y sureste de la provincia del Chaco durante el siglo XVIII. De joven fue domador de caballos y peón de estancia de los españoles de Santa Fe. Pero por diversas circunstancias inició ataques a la jurisdicción de Córdoba, junto con otras etnias, convirtiéndose en un reconocido y temido líder. Tuvo un destacado rol como mediador en los acuerdos de paz entre los abipones y los españoles, conocidos como la Paz de Añapiré y la Paz de San Jerónimo, y como colaborador en el poblamiento y desarrollo de las misiones jesuíticas de San Jerónimo del Rey (actual Reconquista) y San Fernando del Río Negro (actual Resistencia) (Lucaioli, 2011).

${ }^{19}$ El teniente de gobernador, capitán general y justicia mayor Francisco Antonio de Vera Mujica y Torres, nació en Santa Fe en 1707 y falleció en la misma ciudad en 1771 contando con 64 años de edad. De prominente familia santafecina, reemplazó en el cargo a Echagüe y Andía, luego de su sorpresiva muerte, y donde se mantuvo por 24 años ininterrumpidos, entre 1742 y 1766. Bajo su gestión debió afrontar conflictos interétnicos y cuestiones fronterizas, tanto con métodos persuasivos como en el frente de batalla, fundando cuatro pueblos de mocovíes, abipones y charrúas. Su labor fue reconocida por sus contemporáneos, logrando a su vez cimentar un poder socio-económico (Lucaiolli, 2015).
} 
al Padre Joseph Cardiel, natural de la Guardia, para que el zelo extraordinario de este fervoroso Jesuita tuviesse algun cebo también en esta reciente fundacion, y al dicho Padre Navalon para compañero en ella del Padre Joseph Brigniel, principal Doctrinero, entonces ausente concluida la formacion del Pueblo, y dada en nombre de su Magestad juridica possession á los Indios del terreno prescripto por las reales leyes de Indias, dieron la vuelta a San ${ }^{\text {ta }}$ Fee de Vera Cruz el Sen ${ }^{\text {or }}$ theniente $\mathrm{D} o^{\text {n }}$ Francisco Antonio de Vera, y Muxica, y el Padre Rect ${ }^{\text {or }}$ Diego de Horbegoso. Demorose en el mismo Pueblo el Padre Joseph Cardiel, en compañia del Padre Navalon por dos meses hasta la venida á el del Padre Brigniel.

Los sobredichos Padres Francis ${ }^{\mathrm{co}}$ Navalon, de Olmeda de las Valeras en la Mancha de Cuenca, y Joseph Brigniel emprendieron desde luego la ardua empresa de lidiar con la Nacion Abipona, gente sobervia, é indomita, y casi insugetable á la ley Divina y humana, y en circunstancias de ser su barbaro, y dificultoso lenguaje á ellos, y á los demás Jesuitas, peregrino, é incognito, como á los españoles fuera de tal qual cautivo, que malamen ${ }^{\text {te }}$ lo entendia, y peor lo hablaba. Trabajaron estos dos incansables missioneros en imbuirlos en los solidos principios de nuestra $\mathrm{S}^{\text {ta }}{ }^{\text {ta }}$ fee, pero con poco fruto por no querer tenaces dexar sus barbaras costumbres, estudiar su lengua, y desarraigar de sus corazones vn quasi insito odio (propiedad casi de todo Indio) de ellos concebido contra el nombre español, é imponerlos pero con mas provecho en la obediencia debida á su Señor, y nuestro, el Monarca de las Españas.

Mostró singularmen ${ }^{\text {te }}$ entre todos los Abipones en repetidas ocasiones haver del todo depuesto este aborrecimien ${ }^{\text {to }}[4 \mathrm{v}]$ al español, y arraigado solidamente en su corazon el amor naturalmente forzoso acia nuestro Rey, el celebre Cacique Joseph Benavides, el qual á costa de desvelos proprios, continuos peligros de la vida, muertes de sus connacionales, y parientes, y aun de su mismo Primo el Petizo $^{20}$, Cacique distinguido entre los suyos, y temido por su valor de todos, procuró eficazmente estorvar todo daño al español. En las paces generales arriba mencionadas convinieron entre si los Caciques Abipones de librar de todo arrebato enemigo todas las Ciudades, y jurisdicciones, y nombradas las tres Provincias: Paraguay. Rio de la Plata, y Tucumán, con las Missiones de Guaranis. Señalaronse mutuamente términos para la defensa tres entre todos los demás de la nación Abipona principalmente caciques, á saber, y por su orden: Joseph Benavides tomó gustoso á su cargo el custodiar, guardandolas de todo atropellamiento enemigo, las Ciudades de Cordoba del Tucumán, y San ${ }^{\text {ta }}$ Fe de Vera Cruz con todas sus casi interminables jurisdicciones, cerrando del todo por la parte de su Pueblo perteneciente al gobierno de Buenos Ayres, y jurisdiccion de San ${ }^{\text {ta }}$ Fee de Vera Cruz los pasos á todo perfido infiel. Alaiquin ${ }^{21}$, que despues fue fundador en la jurisdiccion de Santiago del

${ }^{20}$ Debayakaikin, llamado por los españoles Petiso, fue célebre por su férrea oposición al proyecto de las reducciones, pariente pero enemigo de Ychoalay quien luego de matarlo, puso su cabeza en un poste en la reducción de San Fernando (Lucaioli, 2011). Debayakaikin tuvo cuatro hijos de distintas madres y al que se refiere ampliamente Dobrizhoffer.

${ }^{21}$ Alayquín fue el primer cacique mocoví bautizado, junto a su mujer e hijos. Uno de ellos, llamado Pachieki, lo sucedió. Cuenta Dobrizhoffer que a Alaykin, cacique de la reducción de Concepción, fue capturado por sus enemigos quienes lo asaron y se lo devoraron. 
Page. La relación sobre las costumbres y poblados de los mocovíes y abipones tutelados por jesuitas, escrita...

Estero del Pueblo de Nuestra ${ }^{\mathrm{a}}$ Seño ${ }^{\text {ra }}$ de la Concepcion ${ }^{22}$, acceptó de grado el oponerse a que entrasse por su lado en las Ciudades de Salta, Tucumán, Santiago del estero, y en sus dilatadissimas jurisdicciones, infiel alguno, que no fuesse verdadero amigo del español. La misma oposicion ofrecio de suyo hacer el valeroso Cacique el Petizo á todo aquel que averso al español intentasse saliendo de los montes, é interminables campos del Gran Chaco, meterse en las Missiones de Guaranis, y jurisdicciones de gobierno del Paraguay, y Ciudad de las Siete Corrientes [5] por aquellas partes, y lados, en que años arriba se fundaron y de la misma nacion Abipona, los Pueblos de $\mathrm{S} a^{\mathrm{n}}$ Fernando $^{23}$, y Nuestr ${ }^{\text {a }}$ Seño $^{\text {ra }}$ del Rosario ${ }^{24}$. Asseguradas tan firmemente en sus fronteras con defensores tan poderosos las tres Provincias españolas sobredichas, entró dentro de poco hostilizando en la jurisdiccion de la Ciudad de Assumpcion del Paraguay, y Missiones de Guaranis, un Cacique Abipon, llamado Huarcaiquin ${ }^{25}$, sin haver en el Petizo encontrado el mas minimo estorvo.

Sintio sobremanera esta deslealtad al español Joseph Benavides, sabedor del atentado de Huarcaiquin. Para desfogar su enojo, y dar satisfaccion á todos, castigando al delinquente, avisó al Petizo de la obligacion, en que se hallaba, por haver el apressor metidose por su lado en las tierras españolas ya pobladas, de corregirle severamente. No satisfecho Benavides con esta diligencia, retardada la correccion del culpado, passó prompto con pocos de los suyos á las tierras, donde estaba Huarcaiquin para darle vreve, y por si mismo el castigo, confiado, en que el Petizo no se opondria. Llegado á ellas, y observando hallarse Huarcaiquin protegido al disimulo del mismo Petizo, y con numero de gente superior al suyo amparado, desesperado ya de conseguir por suplicas de otro lo, que justamente pedia, recurrio imperterrito á las armas, acometiendo animoso á Huarcaiquin, y á todos sus protectores, que siendo tantos, y dispuestos de antemano para

${ }^{22}$ La reducción de la Purísima Concepción o Concepción de la Divina Madre de abipones, se fundó en 1749 en la ribera oriental del río Inespín. Fue promovida por el santiagueño Cristóbal Amaraz que vivió casi toda su vida como cautivo de los abipones, aunque tuvo mujer e hijos abipones que les fueron arrebatados por los españoles. Fue Amaraz quien convenció al cacique Alaykin para que fueran reducidos y el teniente de gobernador Francisco Barreda hizo construir con sus soldados, en el sitio elegido por el cacique, una modesta capilla y habitaciones para los PP. José Sánchez y Bartolomé Araoz, este último reemplazado a los pocos meses por el P. Casado. La reducción fue traslada, tres años después, más cerca de la ciudad de Santiago del Estero y Alaykin decidió abandonarla, hasta que llegó el P. Dobrizhoffer y regresaron (Page, 2012, pp. 335-336).

${ }^{23}$ En la fundación de San Fernando participaron el teniente de gobernador de Corrientes sargento mayor don Nicolás Patrón Cantellas y su par santafecino, además del jesuita P. Vicente Ángel Zaragoza y el cacique Gregorio Naaré de los abipones yaaukanigás. Estos últimos eligieron un sitio en la margen occidental del Paraná, sobre el río. Con la autorización del gobernador, Patrón y varios soldados correntinos, junto a los PP. Tomás y José García, construyeron una capilla y tres aposentos para los jesuitas, rubricando el acta de fundación el 26 de agosto de 1750 en la que se le dio posesión del pueblo al cacique mencionado (Page, 2012, pp. 333-334).

${ }^{24}$ La reducción de Santo Rosario y San Carlos del Timbó fue fundada el 24 de noviembre de 1763, luego de la paz alcanzada entre el gobernador del Paraguay José Martínez Fontes con el cacique Guachichi de los abipones del Bermejo. Se ubicó donde hoy se encuentra la población de Herradura en la provincia de Formosa y estuvo inicialmente a cargo del P. Dobrizhoffer, quien la representó en momentos que era atacada por tobas y mocovíes rebeldes (Page, 2012, p. 337).

${ }^{25}$ No hemos localizado este nombre. 
el lance, hubo de ceder el campo, atendiendo solamente con la fuga á la conservacion de su vida. Poseido de la venganza dio Benavides ligero la vuelta á su Pueblo de $\mathrm{S} a^{\mathrm{n}}$ Geronimo, en donde reforzado de gente se previno para una guerra ofensiva, y defensiva, resuelto á no fenecerla, ni bautizarse tampoco sin primero haver borrado su afrenta con el castigo de aquel, que per[5v]tido havia engañado al español, faltandole á su palabra, y á el, por defender al culpado, metiendole con cautela en el ultimo peligro.

Ensangrentaronse de una, y otra parte altamente los animos que mantuvieron sin intervalo el mas minimo con efusion grande de sangre, y perdida mutua de bienes por espacio de diez años hasta la muerte del Petizo toda suerte de hostilidades. Por todo este largo tiempo en el Pueblo de $\mathrm{S} a^{\mathrm{n}}$ Geronimo todo era confusion, y alboroto, continuos arrebatos de los enemigos, y vigorosos insultos contra el Pueblo, y sus haciendas. No desampararon en estos peligrosos lances los Mocovis de $\mathrm{S} a^{\mathrm{n}}$ Xavier á los Abipones de $\mathrm{S} a^{\mathrm{n}}$ Geronimo y a sus hermanos entre si, y con el español, corriendo á costa de fatigas á su auxilio. Vez huvo que por librarlos de un grave peligro, y á su Pueblo de imminente r[ilegible]na, salieron con la noticia repentina al anochecer del Pueblo de $\mathrm{S} a^{\mathrm{n}}$ Xavier, quarenta arrestados Mocobis, por no hallarse otros dispuestos por la celeridad del aviso, y aparecieron al amanecer en $\mathrm{S} a^{\mathrm{n}}$ Geronimo haviendo caminado en sola aquella noche quarenta leguas, que ay entre uno, y otro Pueblo de distancia, a su arribo en $\mathrm{S} a^{\mathrm{n}}$ Geronimo encontraron á los enemigos de Benavides, y suyos, que ufanos con el despojo de los animales de todas las haciendas del Pueblo, y [ilegible]da recelosos de Benavides entonces gravemente enfermo, desafiaban confiados á todos sus contrarios los moradores del mencionado Pueblo de $\mathrm{S} a^{\mathrm{n}}$ Geronimo. Nada acobardados los Mocobis de $\mathrm{S} a^{\mathrm{n}}$ Xavier con el enemigo victorioso, y poderoso por su multitud excesiva, acometieron con tanta furia al contrario que a los primeros encuentros, muertole algunos, y puesto en huida á todos, sin daño notable proprio, se apoderaron [6] del hurto, que gloriosos volvieron prompto á sus dueños.

Con esta, y otras muchas baterias, intentaba el Petizo, y los infieles de los montes sus auxiliares, destruir inmediatamente aquella nueva fundacion, ó impossibilitar por los frequentes hurtos su subsistencia: con las muertes en algunos de sus habitantes disminuir su numero, retraer á otros, que á ella se agregassen, á los ya agregados que la desamparassen. Joseph Benavides con Niripuri, su tio, y Cacique fundador del Pueblo, procuraban anxiosamente verse con la muerte del Petizo libre, y conservar por medio de ella inviolablemente, y sin ocasion de sospecha la paz sinceramente prometida al español, pero algunos vecinos de su Pueblo de $\mathrm{S} a^{\mathrm{n}}$ Geronimo, observadores de todos sus movimientos, daban con toda cautela de ellos al Petizo infieles prompta noticia, estorvando á Benavides, y Niripuri, el logro de sus deseos. Pero siempre solicitos estos dos celebres Caciques de acabar con este enemigo comun del español, y de los indios á el sugetos, fueron incansables con los Mocobis de $\mathrm{S} a^{\mathrm{n}}$ Xavier, sus auxiliares á la conocida Laguna Blanca, en donde sabian hallarse el Petizo con su gente. Tan deseoso iba Niripuri de acabar con su contrario que, sin esperar a que Benavides con su gente se le incorporasse, acometio, llegado al puerto señalado, con algunos de sus Abipones, 
Page. La relación sobre las costumbres y poblados de los mocovíes y abipones tutelados por jesuitas, escrita...

y los Mocobis sus amigos á las tolderias enemigas, pero tan infaustamente que á pocos encuentros atravesado un ojo á violencia de una flecha cayó impensadamente muerto.

Era tal el brio de los enemigos, que á los primeros acometimientos obligaron á los de Niripuri, y á no pocos de los Mocobis, á retroceder huiendo, pero [6v] rehechos estos con el valor de sus invencibles Capitanes los Caciques de $\mathrm{S} a^{\mathrm{n}}$ Xavier, que sin volver pie atras iban ganando terreno, se enardecieron tanto que á costa de muchas vidas enemigas se hicieron seguros dueños del campo. Vista luego la imposibilidad de encontrar (por haver estado ausente) al Petizo, se ocuparon en cautivar mugeres, y niños, mientras Benavides con la noticia á su llegada de la muerte de su tio desfogaba su enojo, matando algunos fugitivos, aprisionando á otros, y cerrando el passo á todos para la huida. Acompañados de muchos cautivos volvieron triunfantes á su Pueblo de $\mathrm{S}^{\mathrm{n}}$ Xavier los Mocobis todos, viniendo pocos heridos, tristes por la muerte de su Cacique Niripuri entraron también y con muchos cautivos los Abipones en su Pueblo de $\mathrm{S} a^{\mathrm{n}}$ Geronimo, pero esperanzados de que su contrario el Petizo los dexaria por la disminucion de fuerzas suspender quietos las armas.

El Petizo debilitado no poco por la falta de gente para hacer abiertamente, y á las claras frente á Benavides, procuró mañosamente cubrir, y con ventajas esta falta. Valiose del ardid de mantenerse, quando menos se pensaba, por algunas temporadas con su gente en emboscada en las cercanias del Pueblo de $\mathrm{S} a^{\mathrm{n}}$ Geronimo, de donde solo salia para matar á los que sin reserva, y solos se desviaban de el, y passeaban por los campos. Con este artificioso medio enflaquecia poco á poco á Benavides sus fuerzas, y le desarmaba para la guerra. Determinados salieron del Pueblo de $\mathrm{S} a^{\mathrm{n}}$ Geronimo acia las tolderias del Petizo treinta esforzados guerreros para hacer con igual treta en su cercanias no inferior carniceria en los contrarios, pero retrocedieron luego sin llegar á ellas obligados de las aguas. [7] A la vuelta caminando, como ellos suelen, dispersos, cercanos á su Pueblo divisaron tres de ellos al pie de un monte caballos ensillados, y, confiados de ser gente de su Pueblo, gustosos fueron luego á averiguarlo, y encontraron á su dueño el Petizo, que los desnudó á todos, mató a dos, y dio la vida al tercero por razon de muy proximo parentesco, mas lo despachó desnudo de aquella suerte sobre un caballo sarnoso, y en pelo, á su Pueblo de $\mathrm{S} a^{\mathrm{n}}$ Geronimo. A vista de tan enorme, y manifiesta infamia, se conjuraron los moradores todos de $\mathrm{S} a^{\mathrm{n}}$ Geronimo de acabar con el Petizo, cooperando eficazmente desde entonces á los intentos de Benavides. Para lograr vrebe, y con menos riesgo de los suyos la muerte de tan nocivo enemigo baxó sin detenerse á la Ciudad de $\mathrm{San}^{\text {ta }}$ Fee de Vera Cruz el referido Benavides, solicito de españoles en su auxilio el Señ ${ }^{\text {or }}$ theniente $\mathrm{D} o^{\mathrm{n}}$ Francis ${ }^{\mathrm{co}}$ Antonio de Vera, y Muxica no se los dio, ni fue possible á causa de estar estos ya en otra parte, y por orden urgente del exelentisi ${ }^{\mathrm{mo}} \mathrm{Sen}{ }^{\text {or }}$ Governador de Buenos Ayres, empleados en el real servicio. Perdidas las esperanzas de este auxilio lo buscó en los Mocobis de $\mathrm{S} a^{\mathrm{n}}$ Xavier, cuyos Caciques, por obligarle al bautismo, le respondieron: que ya no le ayudarían hasta que fuesse christiano, y por el bautismo sin dar lugar á dilaciones se hiciesse de ellos verdaderamente Hermano. Con esta no esperaba respuesta partio desabrido para su Pueblo de $\mathrm{S} a^{\mathrm{n}}$ Geronimo, y al dia siguiente de su arribo á el salio solo con su gente en busca del Petizo para no tornar á el sin su cabeza. 
A algunos dias de camino noticioso Benavides de hallarse el precitado Petizo de visita en la tolderia de Pachacaé, ó Alaiquincito ${ }^{26}$ segun los españoles, se acercó á ella, $\mathrm{y}$, á las tres, ó cinco leguas antes de llegar, por algunos de [7v] los suyos le hizo cierto de su arribo á aquellas partes, y de sus animos, provocandole á batalla. A esta noticia imperterrito preguntó el Petizo: vienen Mocobis? Se le asseguró que no vienen españoles, prosiguio diciendo Certificado de no venir ni unos, no otros, respondio arrogante: decidle á esse Indio (assi llamaba por desprecio á Benavides) que presto estaré con el Joseph Benavides con su gente fatigado del viage, de las lluvias, y de el hambre, difirio á gusto de su contrario para el dia siguiente el combate. En el convenidos los dos opuestos Caciques sobre el sitio y modo de la pelea, y quedando tambien por mutuos puntos fuera de todo riesgo el Hijo del Petizo, y uno de los sobrinos de Benavides, por aun incapaces de armar sus dos hijos, para tomar cada uno por su parte en lo por venir venganza por el vencido, ó muerto. Joseph Benavides con los suyos, y el Petizo auxiliado del valiente Pachacae, y su gente, emprendieron una sangrienta guerra, en la que á pocos choques cayó muerto el Petizo, y Pachacae con su gente, satisfecho Benavides, tomó seguro la huida.

Volvio prompto con su gente Benavides á su Pueblo llevando por trofeo la cabeza de su contrario, que para escarmiento aun formados sus soldados, y sin echar pie á tierra, sobre tres palos, dexó pendiente en la plaza. Vinieron algunos de los suyos heridos, pero ninguno quedó muerto. Libre ya de este capital enemigo, y alborotador publico bien instruido recibio solemnemente en la Ciudad de San ${ }^{\text {ta }}$ Fee de la Vera Cruz con su futura muger Joseph Benavides el Sacramento del Bautismo y luego imediatamenteen presencia del Padre Joseph de Lehmann ${ }^{27}$, su segundo Missionero, y sin igual hasta ahora lenguaraz insigne de los dos dificilisimos idiomas, Mocobi [8] y Abipon, el del Santo Matrimonio. Condecoraron personalmente en señal de su alegria, y cumplimiento de sus deseos, estos dos sagrados actos los Señores Cabildos, eclesiastico, y secular de dicha Ciudad de San ${ }^{\text {ta }}$ Fee de Vera Cruz, y todas las comunidades religiosas, con repique general de campanas, y estruendo de muchos artificiales fuegos. El Señ ${ }^{\text {or }}$ Theniente D $o^{\mathrm{n}}$ Francis ${ }^{\mathrm{co}}$ Antonio de Vera, y Muxica no satisfecho de honrar con su respetable presencia, y en qualidad de padrinos, á los dos recien bautizados, y casados in facie ecclesiae, les mostró á expensas proprias grandes el consuelo de su corazon por verlos ya con el bautismo hijos de Dios, verdaderos vasallos de nuestro monarca. Fueronse despues sucesivamente con intervalo de algunos años fundando los otros tres Pueblos Abipones: el de Nuestra ${ }^{\mathrm{S} e n ̃ o}{ }^{\mathrm{ra}}$ de la Concepcion en la jurisdiccion de Santiago del Estero de la Provinci ${ }^{\mathrm{a}}$ del Tucumán, el de las Siete Corrientes de la del Rio de la Plata, el de Nuestra Seño ${ }^{\text {ra }}$ del Rosario en la de la Assumpcion de la del Paraguay.

\footnotetext{
${ }^{26}$ Pachieki, o como acá lo llama el P. Bustillo, Alaiquincito, por ser hijo del cacique abipón Alayquín, a quien sucedió en el gobierno.

${ }^{27}$ El P. Lehmann nació en Landeck, antiguo reino de Prusia que hoy pertenece a Austria, el 22 de noviembre de 1723. Llegó a Buenos Aires con la expedición de Ladislao Orosz en 1749, año en que profesó sus primeros votos, mientras los últimos los hizo en 1762. La expulsión lo sorprendió en la reducción de San Jerónimo de abipones. Se desconoce dónde murió y se tiene como última noticia conocida en 1773, cuando residía en Wiener-Neustadt, un pueblo de la Baja Austria ubicado a poco más de quinientos kilómetros de su alpina ciudad natal (Storni, 1980, p. 159). Fue misionero en San Javier y San Jerónimo.
} 
Page. La relación sobre las costumbres y poblados de los mocovíes y abipones tutelados por jesuitas, escrita...

Merecen singular memoria en estas fundaciones, y en las paces generales sobredichas con los Indios, por haverlos con su valor, modales catolicos, y donativos proprios, dispuesto para ellas, los Señores thenientes de Governadores de la Ciudad de Vera Cruz D $o^{\mathrm{n}}$ Francis $i{ }^{\mathrm{co}}$ Xavier de Echague, y Andia, y D $o^{\mathrm{n}}$ Francis ${ }^{\mathrm{co}}$ Antonio de Vera, y Muxica, y el Señ ${ }^{\text {or }} \mathrm{D} o^{\mathrm{n}}$ Francis $^{\mathrm{co}}$ de la Barreda ${ }^{28}$ de la de Santiago del Estero, que con su presencia, gastos de haveres proprios, coadiuvó, y fomentó el Pueblo de su jurisdiccion llamado Nuestr ${ }^{\text {a }}$ Seño ${ }^{\text {ra }}$ de la Concepcion, y despues, sin reparar en la cortedad de sus medios, la amparó con tanta eficacia, como antes de las paces con [8v] algunas correrías contra Mocobis, y Abipones, matandoles varios y cautivandoles muchos, los obligó con la esperanza de recobrar unos sus parientes, otros sus mujeres, é hijos, y todos sus connacionales, y paysanos, y no interrumpidas persuasiones de los Jesuitas, á convenir en las paces generales, y sus tratados, el Señ ${ }^{\text {or }} \mathrm{D} o^{\mathrm{n}}$ Phelipe de Zevallos ${ }^{29}$, de la de las Siete Corrientes, que con su incomparable valor, y astucia rara en los ardiles de la guerra contra estos barbaros, los contuvo en su deber, haciendo de ellos respetables las tierras de su comando, y las hubiera conservado libres sp[ilegible] de todo daño, que en lo por venir sintieron, si la embidia enemiga de agenos aplausos no le huviera removido del empleo, que dignamente exercia.

Establecido ya en el Pueblo de San Geronimo Joseph Benavides ayudó notablemente a la formación de los tres referidos Pueblos, que despues se fundaron, mayormente á la de $\mathrm{S} a^{\mathrm{n}}$ Fernando, á cuyos moradores obligó con las armas, de los montes se retirassen á Pueblo, y en el se mantuviesse hasta nuestro destierro con su Cacique nombrado Naré $^{30}$. Trajolos primero como cautivos de los montes á su Pueblo de $\mathrm{S} a^{\mathrm{n}}$ Geronimo en donde á el sujetos procuró el Señ ${ }^{\text {or }}$ theniente de las Siete Corrientes $\mathrm{D} o^{\mathrm{n}}$ Nicolas Patron ${ }^{31}$ conseguir del mismo Benavides, como lo logró, el formar con ellos para valuarte, y defensa de su Ciudad, y jurisdiccion, el mencionado Pueblo de $\mathrm{S} a^{\mathrm{n}}$ Fernando.

\footnotetext{
${ }^{28}$ Francisco de la Barreda y Sanmartín fue teniente de gobernador de Tucumán en 1744 y posteriormente de Santiago del Estero desde 1749, sucediendo a José de Aguirre y Araoz. Escribió una Breve relación de la fundación de la Concepción.

${ }^{29}$ El sargento mayor Felipe de Zeballos fue teniente de gobernador de Corrientes entre 1745 y 1748, cuando lo sucedió Nicolás Patrón. Zeballos ordenó asesinar al cacique Chilomé y un grupo de abipones en su propia casa. La venganza se desató con la unión de abipones, mocivíes y tobas bajo el mando del cacique Ychamenraikín que atacaron no solo la ciudad de Corrientes, sino también Santa Lucía y la estancia de Rincón de Luna. Todo ello provocó el éxodo de los correntinos a Santa Fe y Asunción (Page, 2019, p. 141).

${ }^{30}$ El cacique abipón Naré (fuego) habitaba las costas del Paraná. En la actualidad una ciudad de Santa Fe lleva su nombre. Era hermano del cacique Pachieké de los abipones jaaukanigás (gente del agua). Dobrizhoffer (1970) escribió que era de "noble origen e insigne por sus hechos militares, pero escaso de fuerzas mentales y físicas, notablemente mujeriego y borracho. Más inclinado al ocio que al trabajo demostró siempre un espíritu indolente".

${ }^{31}$ Como dijimos, el hidalgo andaluz maestre de campo Patrón y Centellas sucedió a Zeballos en el cargo de teniente de gobernador de Corrientes en el período 1746-1758, con una marcada simpatía por la Compañía de Jesús, lo que le valió la antipatía del bando antijesuítico de la familia Casajús. Se radicó en Corrientes en 1742 y tres años después contrajo matrimonio con María Antonia de Zamudio. Durante su mandato hizo 32 campañas contra los indios, que le valió el título de maestre de campo general otorgado por el gobernador del Río de la Plata José de Andonaegui. Pasó luego como gobernador de la provincia de Huanta en Perú (Labougle, 1978).
} 
A pocos meses formado el Pueblo de $\mathrm{S} a^{\mathrm{n}}$ Geronimo aparecio, en el entre los nuevamente salidos de los montes un indio á caballo con un bonete de Jesuita en la cabeza, que renovó no poco á los Padres Missioneros el sentimiento por la muerte que violentamente los mismos Abipones dieron al Padre Santiago [9] Herrero ${ }^{32}$, suyo havia sido. Encontrolo casualmente el Padre Francisco Navalon en una calle del Pueblo, y poseído del dolor sin reparar en peligros se lo quito arrebatadamente al Indio de la cabeza tambien desde el caballo, en que iba. Fue necessaria toda la authoridad de Benavides, para que el lance no fuesse origen preciso de malas consequencias, por ser el Indio entre los suyos de mucho nombre, y valor, y haverse agraviado demasiado. Passó el Padre Santiago Herrero de la Provincia entonces de Castilla á la que en otro tiempo fue del Paraguay. Acabada su tercera Probacion caminando por obediencia desde la Ciudad de Cordoba del Tucumán para las Missiones de Guaranis en el camino para la Ciudad de San ${ }^{\text {ta }}$ Fee de Vera Cruz el año de 1747 le quitaron con otros españoles sus compañeros la vida los barbaros Abipones. Despojaronle primero de todas sus alhajitas, y aun de su proprio vestido, dexandole en camisa, y calzoncillos, que no queriendo por modestia alargar, sediciosos le dieron un mortal lanzazo. Entre otras cosas del Padre Herrero se llevaron los matadores el referido bonete, que conservaron por mas de un año en los montes, y despues sin haverle dado nueva forma, cosa rara por la voluvilidad del indio en su cosas, y acciones, ni aun immutandole, increíble á los practicos de su genio, en manera alguna, lo trajeron al nuevo Pueblo de $\mathrm{S} a^{\mathrm{n}}$ Geronimo. El mencionado $\mathrm{P} a d r^{\mathrm{e}}$ Navalon, restaurado el sobredicho bonete, lo arrojó sobre el cielo de su cama, en donde cubierto de polvo se mantuvo hasta los doce años venideros, que por casualidad al cabo de ellos buscando otra cosa se encontró libre de toda polilla en tierra sumamente á ella expuesta. Lo que yo puedo decir es que antes de tres años de Missionero en aquellas mismas tierras me hallé con el, que á ellas llevé nuevo, cubierto, y ahugereado en muchas partes de la polilla, [9v] aun usando varias veces, y limpiandolo no pocas. Observada por los Padres Missioneros en el bonete tan extraordinaria novedad, y haciendo reflexión á la vida inculpable que siempre conservó entre nosotros el Padr ${ }^{\mathrm{e}}$ Santiago, se guardó en lugar ya mas decente hasta nuestro destierro, en que el mismo Padr $r^{\mathrm{e}}$ Navalon por cierto derecho de antelacion á todos se lo traxo consigo, y guardo en su compañía para consuelo proprio. Este caso, aunque parezca, y sea digression, me ha parecido insertar aquí por algunos no leves fundamentos.

Noticioso el Excelentísi ${ }^{\text {mo }}$ Señ ${ }^{\text {or }}$ Governador de Buenos Ayres Do ${ }^{\text {n }}$ Pedro de Zevallos como vice Patrono del proceder de estos Pueblos de su govierno en la fee, amor á nuestro Soberano, y utilidad de la republica, escribio entre todos los demas á los Caciques del Pueblo de San Francis ${ }^{c o}$ Xavier por sus especiales servicios a Dios, al Rey y á las Ciudades españolas en aquellas partes una carta gratulatoria, honrandolos en virtud de ella, y en nombre de su Magestad con el baston de Capitanes de aquel su

${ }^{32}$ El P. Santiago Herrero nació en Rubí de Bracamonte, Valladolid, el 25 de julio de 1717, ingresando a la Compañía de Jesús de la provincia de Castilla en 1736. Llegó a Buenos Aires en la expedición de los PP. Diego Garvia y Juan José Rico en 1745 y tras completar sus estudios en Córdoba fue enviado a las reducciones de Santa Fe, siendo atacado por los abipones que le dieron muerte en las cercanías de Río Tercero el 18 de febrero de 1747 (Page, 2011, pp. 41-70). 
Page. La relación sobre las costumbres y poblados de los mocovíes y abipones tutelados por jesuitas, escrita...

Pueblo, exhortandolos juntamente a que con toda eficacia solicitassen la reduccion á Pueblo de todos sus connacionales, y parientes. Recibiose con todo aplauso y respeto en $\mathrm{S} a^{\mathrm{n}}$ Xavier esta carta, que besada, puestos de rodillas, por los principales de el, á vista de todo el Pueblo descubierto, y con toda la posible veneracion fue leida por un Mocobi perito en lengua española, y diestro en leer, y escribir. El Pueblo de $\mathrm{S} a^{\mathrm{n}}$ Xavier tan honorificamente tratado por su Governador despachó sin demora alguna con la imagen del glorioso Apostol de la India $\mathrm{S} a^{\mathrm{n}}$ Francis ${ }^{\mathrm{co}}$ Xavier para su norte, y guia unos pocos de sus individuos á los montes, ó madrigueras de infieles sus connacionales á persuadirles en nombre de su Excelentisi ${ }^{\mathrm{mo}}$ Governador, sus Caciques, y Padres Missioneros la formación en Pueblo. Volvieron promptos á los dos meses los embaxadores a su Pueblo de $\mathrm{S} a^{\mathrm{n}}$ Xavier la deseada noticia de quedar ya resueltos á juntarse el [10] Pueblo muchos de los Mocobis aun no reducidos, y de venir, empeñada su palabra, dentro de poco al mismo Pueblo de $\mathrm{S} a^{\mathrm{n}}$ Xavier á tratar de la erección de su nuevo Pueblo, en cuyo cumplimiento el año de 1763 por setiembre entraron en el sobredicho Pueblo de $\mathrm{S} a^{\mathrm{n}}$ Xavier trecientos de ellos. Baxó imediatamente el Padr $r^{\mathrm{e}}$ Florian Paucke con algunos de los Mocobis recien venidos, y sus tres Caciques á la Ciudad de San ${ }^{\text {ta }}$ Fee de Vera Cruz á presentarlos al Señ ${ }^{\text {or }}$ teniente $\mathrm{D} o^{\mathrm{n}}$ Francis ${ }^{\mathrm{co}}$ Antonio de Vera, y Muxica, y ver el modo de establecerlos en Pueblo. Fueron humanamente recibidos de dicho Señ ${ }^{\text {or }}$ thenien $n^{\text {te }}$ pero nuevas fundaciones de Indios quando se trataba con todas veras librar por la guerra urgente de Ingleses, y Portugueses las antiguas españolas. Con esta respuesta sin otro fruto volvieron á $\mathrm{S} a^{\mathrm{n}}$ Xavier, en donde aun esperanzados de lograr sus deseos perseveraron algun tiempo, pero advirtiendo retardarse su logro, y desconfiando de el, algunos sin poderlos contener se tornaron á los montes, y otros a persuasiones de los Padres Missioneros se estuvieron quietos.

Con el Cacique principal de estos Mocobis nuevamente agregados se puso segunda vez en la presencia del sobredicho Señ ${ }^{\text {or }}$ theniente el mencionado Padr $r^{\mathrm{e}}$ Florian Paucke en la misma Ciudad de San ${ }^{\text {ta }}$ Fee de Vera Cruz reiterándole la suplica sobre las pretensiones de aquellos pobres infieles. La respuesta en conclusion no mas favorable que la primera fué, que la nueva fundacion por entonces era impracticable, que se agregassen por tanto á la antigua de $\mathrm{S} a^{\mathrm{n}}$ Xavier. El agregarse al referido Pueblo de $\mathrm{S} a^{\mathrm{n}}$ Xavier estos ultimamente venidos Mocobis era del todo inasequible [10v] por faltar fondos al Pueblo para los alimentos de tantos, y lo otro por no querer ellos, ni su Cacique principal sujetarse á Pueblo, que governassen con dependencia alguna agena. Con esta resolucion del Señor thenien ${ }^{\text {te }}$ quedó totalmente disgustado el Cacique, fundador del futuro Pueblo; y con la noticia al mismo tiempo de la muerte de un hijito suyo muy amado, pero ya christiano, en el Pueblo de $\mathrm{S} a^{\mathrm{n}}$ Xavier aquellos pocos dias de su ausencia, se le aumentó notablemente su desazon. El Padre Paucke previniendo que estos dos sensibles golpes con el de haversele en el mismo Pueblo de $\mathrm{S} a^{\mathrm{n}}$ Xavier muerto tambien meses antes una de sus estimadas mujeres serían en el Indio poco fortalecido con la luz de la razon, y de la gracia forzosos antecedentes de infaustas consequencias, acudió sin perdida de tiempo con lenittivos de suaves exhortaciones á dilatar aquel corazon encongido. Suavizose al parecer el pobre Indio, y salio de la dicha Ciudad de San ${ }^{\text {ta }}$ Fe de Vera Cruz en compañía del mismo Padre Paucke resignado. 
A pocas horas de camino para $\mathrm{S} a^{\mathrm{n}}$ Xavier, apartandose de todos sus compañeros, y del Padre Paucke se metio poco á poco taciturno por los montes. Embio luego por los montes en su seguimiento el Padre Florian Paucke algunos Mocobis de su compañia ya christianos antiguos, á que lo consolassen, y llevasen al Pueblo de $\mathrm{S} a^{\mathrm{n}}$ Xavier á donde tambien despachó otros á los Caciques, que lo detuviessen alli hasta su llegada. Ya en el referido Pueblo de $\mathrm{S} a^{\mathrm{n}}$ Xavier el mencionado Padr ${ }^{\mathrm{e}}$ Paucke procuró por todos los medios posibles, disipandole sus sentimientos, contenerle en su compañia en el Pueblo. Partio sin remedio para los montes, dexando á todos menos aflixidos por las promessas [11] de que volveria quanto antes como lo cumplio. Le dio no obstante el Padr $r^{\mathrm{e}}$ Florian para su compañero inseparable, y consejero un único hijo, que le quedaba, y que por muchos años casado in facie ecclesiae, y con mucha edificacion havia vivido en aquel mismo Pueblo de $\mathrm{S} a^{\mathrm{n}}$ Xavier. Al cabo de algun tiempo sin su Padre para desconsuelo universal entró en el de vuelta este mozo, pero Dios consoló á todos volviendo á pocos dias despues al Pueblo este deseado Cacique. A no mucho tiempo de su llegada probó Dios mas á este pobre Cacique con la muerte del referido hijo, que para su consuelo vivo siempre miraba. Mantuvole Dios constante despues de tantos rebeses aun á la vista de este tan imponderable. En el año de 1764, visitando el Ilusttrisi ${ }^{\text {mo }}$ Señ $^{\text {or }}$ Do $o^{\text {n }}$ Manuel Antonio de la Torre ${ }^{33}$, Obispo del Paraguay, y entonces ya de Buenos Ayres, el Pueblo de $\mathrm{S} a^{\mathrm{n}}$ Fran $c i{ }^{\mathrm{co}}$ Xavier, bautizó solemnemente en el, bien instruidas á dos únicas hijas que á falta de varones para su alivio á este paciente Cacique Dios vivas conservaba. Dio su Ilusttrisi ${ }^{\mathrm{ma}}$ á la mayor los nombres de Manuela Antonia, y á la menor de Antonia Manuela, concurriendo personalmente con no poca admiracion, y gozo á este solemne acto aunque infiel su mismo Padre, y dando por remate á su modo en muestras de agradecimiento obligado extraordinarias gracias á su Seño ${ }^{\text {ria }} \mathrm{I} l u s t t r i s i^{\mathrm{ma}}$.

Por Noviembre del mismo año de 64 en cumplimien ${ }^{\text {to }}$ de su oficio passando de visita por aquellos Pueblos el Padr $r^{\mathrm{e}}$ Provincia ${ }^{1}$ Pedro Juan Andreu ${ }^{34}$, Mallorquin de nacion, é hijo de Palma, encontró el Pueblo de $\mathrm{S} a^{\mathrm{n}}$ Francis ${ }^{\mathrm{co}}$ Xavier gravado sumamente con el sustento quotidiano á sus expensas por mas de un año de aquellos nuevos [11v] Mocobis, y á sus moradores por los gastos privados en vestirlos, y proveerlos de lo

\footnotetext{
${ }^{33}$ Manuel Antonio de la Torre (1705-1776) fue el vigésimo quinto obispo del Paraguay (1757-1763) y undécimo obispo de Buenos Aires (1765-1776). Fue el responsable de cumplir la orden de la expulsión de los jesuitas. Escribió un exhaustivo informe que tituló "Razón que de su Visita General da el Dr. Dn. Manuel Antonio de la Torre, Obispo del Paraguay al Real y Supremo Consejo de Indias. Año de 1761". Este texto, iba acompañado originalmente de 12 informes que, en la actualidad se hallan dispersos en el Archivo General de Indias, con los títulos 1- sobre la yerba del Paraguay, 2- sobre administradores de pueblos de indios, 3- sobre el seminario, 4- sobre diezmos de pueblos de indios, 5- sobre nulidad de matrimonios, 6- sobre entierros en los conventos, 7- sobre abintestados, 8- sobre el hospital, 9- sobre el convento de la Villa de Curuguatí, 10- sobre erección de iglesias parroquiales, 11- sobre examen de curatos y 12- sobre la observancia del concilio limense (Aguerre Core, 2007).

${ }^{34}$ El P. Pedro Juan Andreu nació Palma de Mallorca el 26 de noviembre de 1697, ingresando a la provincia jesuítica del Paraguay en 1733. Llegó a Buenos Aires al año siguiente en la expedición del P. Antonio Machoni. En 1736 obtuvo el sacerdocio del obispo de Buenos Aires fray Juan de Arregui y Gutiérrez. Para 1743 estaba en Tucumán donde profesó su cuarto voto, alcanzando a ser provincial del Paraguay para el periodo 1761-1766. La expulsión lo sorprende en Córdoba y muere en Ravena el 24 de febrero de 1777. Una biografía suya en Furlong (1953).
} 
Page. La relación sobre las costumbres y poblados de los mocovíes y abipones tutelados por jesuitas, escrita...

necessario, faltos de lo preciso, á los recién venidos Mocobis, aburridos de esperar, determinados á no parar allí mas tiempo, si promptamen ${ }^{\text {te }}$ no se les proveia de Missioneros, que, separados de los vecinos del Pueblo de $\mathrm{S} a^{\mathrm{n}}$ Xavier los instruiessen, y estableciessen en Pueblo. Muchas, é insuperables eran las dificultades, que retardaban las loables pretensiones de estos miserables Mocobis, la falta de fondos, ni medio de adquirirlos para formarlos en Pueblo, y en el conservarlos, la impossibilidad de lograr por entonces facultad real por estar en aquellas circunstancias el Excelentis $i^{\mathrm{mo}}$ Governador de Buenos Ayres $\mathrm{D} o^{\mathrm{n}}$ Pedro de Zevallos atendiendo únicamente en el gobierno forzozo de las plazas recientemente conquistadas, y en disponerlas con fuertes fortificaciones, y valerosas guarniciones, á una invencible resistencia en caso de segunda guerra contra Ingleses, y Portugueses, y el corto numero de Jesuitas, que para sus multiplicados ministerios entonces tenia la Provincia. Superior á todo estorvo de la conversion de los Infieles el invicto zelo del referido Padr $r^{\mathrm{e}}$ Provincial Pedro Juan Andreu consolo paternalmente á los nuevos Mocobis con las promesas de embiarles quanto antes Missioneros, que los instruiessen, y formassen con real permisso en su apetecido Pueblo. Para cumplir con toda presteza lo prometido rezeloso de alguna incostancia en los infieles Mocobis el Padr $r^{\mathrm{e}}$ Provincial partio sin detenerse á Cordoba del Tucumán, de donde á los dos días del arribo su reverencia á ellas tres de haver yo recibido el Presbiterado, y el mismo dia celebrada mi primera missa el quatro de Diciembre de 1764, por compañero en el pretendido Pueblo del Padre Florian Pau[12]cke, cura actual del Pueblo de $\mathrm{S} a^{\mathrm{n}}$ Xavier, caminé sin demora alguna á incorporarme con dicho Padr $r^{\mathrm{e}}$ Paucke en el mismo Pueblo de $\mathrm{S} a^{\mathrm{n}}$ Xavier, al que llegué el veinte y quatro del proprio mes de Diciembre. Con mi llegada fue increible el gozo de los nuevos Mocobis satisfechos de ver con sus mismos ojos ya puestas por obra sus piadosas intenciones.

El once de enero de 1763 salimos el Padre Florian Paucke, y yo del Pueblo de San Francis ${ }^{\text {co }}$ Xavier con los Mocobis infieles, habitantes del futuro Pueblo, y algunos otros ya christianos, y vecinos del mencionado Pueblo de $\mathrm{S} a^{\mathrm{n}}$ Xavier, que para exemplo con sus edificativas acciones de los recien convertidos, gustosos nos acompañaron, y sirvieron con mucho alivio nuestro en todo lo necessario. Anduvimos algun tiempo por los campos entreteniendolos con gusto en hacer una hacienda de ganado para el proximo futuro Pueblo, en que levantamos un corral capaz de encerrar en su quatro, ó cinco mil bacas. Estableciose esta hacienda en el parage nombrado Mocobi el Matitzatolec, en nuestro idioma el sauzalcillo. Dista este referido lugar del Pueblo de $\mathrm{S} a^{\mathrm{n}}$ Xavier, que mira é su Sur, nueve leguas, siguiendo la costa del gran Rio Raraná, y por el mismo rumbo camino derecho, y trillado para la Ciudad de $\mathrm{S} a n^{\text {ta }}$ Fee de Vera Cruz, y el referido Pueblo de $\mathrm{S}^{\mathrm{n}}$ Xavier, y por el Norte de la misma manera para el de $\mathrm{S} a^{\mathrm{n}}$ Geronimo, y siete del sitio, en que poco despues se fundó el deseado Pueblo de $\mathrm{S} a^{\mathrm{n}}$ Pedro, que observa casi á su Poniente. En estas caravanas nos ocupamos dando lugar a que llegasse por escrito la facultad del Excelentís $i^{\mathrm{mo}} \mathrm{S} e \tilde{n}^{\text {or }}$ Governador $\mathrm{D} o^{\mathrm{n}}$ Pedro de Zevallos para la fundacion del Pueblo, que se intentaba, llamado $\mathrm{S} a^{\mathrm{n}}$ Pedro. Firmose la real facultad para la fundacion por el Excelentísi ${ }^{\mathrm{mo}}$ Governador el dia 9 ú 11 de enero, [12v] ó Febrero de 1765 , señalandose individualmente en ello el terreno para el establecimiento del nuevo Pueblo y ordenandose al teniente de $\mathrm{S} a n^{\text {ta }}$ Fee de Vera Cruz D $o^{\mathrm{n}}$ Francis ${ }^{\mathrm{co}}$ Antonio de 
Vera, y Muxica, á quien se dirigio, diesse juridica, y prompta possession del parage, que se le decía, y fomentasse en lo possible la nueva poblacion. El disgusto de algun otro authorizado Santafesino sobre el sitio prescripto para la formación del Pueblo de $\mathrm{S} a^{\mathrm{n}}$ Pedro demoró á los Indios el consuelo de verse con la possession authorizada señores de el hasta el dia primero de mayo del mismo año de 1765 y á nosotros por consequencia el que que nos corriesen hasta el proprio dia los synodos, que se dan segun real recopilacion de Indias á todos los Doctrineros de Indias. El ocho de Febrero por la tarde caminamos del Sauzalcillo para el Inspin chico ${ }^{35}$, assi se llama el lugar, donde despues se establecio el Pueblo de $\mathrm{S} a^{\mathrm{n}}$ Pedro, y llegamos á el proximo siguiente dia á cosa de las nueve de la mañana, vadeados primero dos ríos, que se encuentran en el camino, y por sus aguas algo salobres se llaman en aquellas partes saladillos: en tiempos de aguas están á nada, y en casi todo el año aun en callo alto llegan sus aguas á los encuentros. Entre el Pueblo de $\mathrm{S} a^{\mathrm{n}}$ Pedro, y el de $\mathrm{S} a^{\mathrm{n}}$ Xavier, que está con poca diferencia á su oriente ay catorce leguas de mal camino en tiempo de aguas por las muchas, que derramandose por los campos de los saladillos sobredichos los ponen intransitables: entre el mismo, y la Ciudad de San ${ }^{\text {ta }}$ Fee de Vera Cruz, que cae á su Sur, 37 leguas; entre el proprio, y el de los Charruás, que tambien cae á su Sur, nombrado Nuestra Seño $^{\text {ra }}$ de la Concepcion de Cayastá, assi se llama el parage, donde está este Pueblo [13] y está á cargo de los Reverendos Padres Franciscanos Observantes: siete entre el referido, y el Pueblo de $\mathrm{S} a^{\mathrm{n}}$ Geronimo de la nacion Abipona, que mira á su Norte, 28, ó 30: y entre el por vltimo, y la celebre Laguna Blanca, sita á su poniente, siete.

Por un lado del Pueblo de $\mathrm{S} a^{\mathrm{n}}$ Pedro como un tiro de piedra distante corre de poniente á oriente un arroyo de agua dulce, que teniendo su origen en unos manantiales retirados de $\mathrm{S} a^{\mathrm{n}}$ Pedro como dos leguas desagua en el saladillo mas próximo á el de los dos arriba mencionados, y apartado como un quarto de legua acia su Oriente. En este arroyo de agua dulce se encuentra una multitud inmensa de sabalos, abundancia de vagres, palometas, y crecido numero de cocodrillos, ó yacarés segun frase de aquellas tierras. No sé ciertamente en que altura está el sobredicho Pueblo de $\mathrm{S} a^{\mathrm{n}}$ Pedro, pero sospecho que está entre los 29, ó 30 grados. Fundose sobre una lomeria vistosa, y continuada casi por algunas leguas, mayormente de Sur á Norte, y á su Oriente en distancia de casi media legua, passado el primer Saladillo, ay una laguna mediana de agua salada, y otra mayor pero bastante caida sobre el Norte, y poco mas retirada, que parece en tiempo de aguas un mar chiquito. El pez palometa arriba nombrado se halla con abundancia, y frequentemente en los arroyos, y lagunas de todas aquellas partes. Sus quixadas á manera de sierra son tan agudas, que el hombre, que entra á bañarse en ellos, necessita de especial cuidado para no salir menos hombre. Los Indios á falta de cuchillos se valen para sus menesteres de estas quixadas, de tixeras les sirven para trasquilar ovejas, y de lancetas para sangrarse.

Ay por aquellas partes variedad de animales, raros comparados con los de Europa, pero ordinarios, y obvios [13v] en la America Occidental, como por ejemplo, ossos hormigueros, capiguaras, animal anfibio, como tambien son las nutrias, de cuya

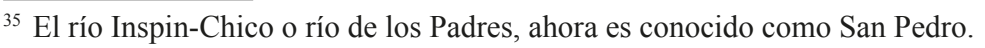


Page. La relación sobre las costumbres y poblados de los mocovíes y abipones tutelados por jesuitas, escrita...

piel se hacen de vestir los Indios y los españoles se valen de ellas para cobertores de cama, cocodrillos, tigres, leopardos, avestruces, gamas, que son á manera de cabras sin hastas, zorrinos, animal no tan grande coo un gato, de color hermoso, y de pelo muy fino. Para defenderse de sus enemigos se vale en lugar de armas de su pestilente orina, de que por mas que descargue se halle siempre proveido. Son tambien raras y ordinarias de la misma suerte muchas de las aves, que por alli se encuentran. Las sierpes ${ }^{36}$, y vivoras de varias especies en aquellos parages, como tambien en todas las otras tierras de los tres goviernos: Paraguay, Rio de la Plata y Tucumán, son muchas, y venenosas, entre las que se halla la vivora, llamada de cascabel. El sitio de $\mathrm{S} a^{\mathrm{n}}$ Pedro, el del Pueblo de $\mathrm{S} a^{\mathrm{n}}$ Xavier, y $\mathrm{S} a^{\mathrm{n}}$ Geronimo es excelente para poblacion, de bellissimos campos por su abundancia de pastos, y aguadas, sin igual para la cria de animales bacunos, ovejunos, y mulares. En ellas por lo comun, y en todo tiempo del año se hallan las bacas muy gordas, y muchas con cinco, ó seis arrobas en grassa, y sebo, y estas solas son las que con especialidad tienen el nombre de gordas. Estos campos desde las inmediaciones de la Ciudad de San ${ }^{\text {ta }}$ Fe de Vera Cruz hasta los referidos Pueblos van entretexidos de montes claros, y abundantes de algunas buenas maderas, y los forman en muchas partes, y con mucha gracia y en forma de islas, ya de penínsulas, pero de $\mathrm{S} a^{\mathrm{n}}$ Geronimo adelante caminando al norte se van cerrando de suerte que apenas dan lugar al passo de un hombre á caballo, y assi continúan hasta el sitio nombrado de Fragadero, que está en los contornos del Rio Grande entre el Paraguay, Salta, y Corrientes, y es el parage en donde habitan por lo comun muchas naciones del Gran Chaco.

[14] En los arboles se encuentra mucha variedad. El ombu, ó embuco es un arbol vistoso, se cria muy gruesso, alto, copudo, de oja grande, y muy fofo, quitada la corteza parece todo una filigrana. No tiene otra utilidad que librar con su apacible sombra el tiempo de verano de los ardores del sol á los, que se ocupan en obrages de madera, y de el quebracho colorado, llamado quiebraachas por las que quiebra al derribarlo, ó cortarlo. La dureza, y duracion de su corazon puramente colorado puede competir con la del hierro. Se rompe, y ara con el la tierra como con una buena reja de hierro, y sirve este arbol para muchas obras. El espinillo, ó Nandubaij clavado en parte humeda, ó dentro del agua se convierte en pedernal, y solo el fuego lo puede consumir. A las dieciseis leguas mas alla del Pueblo de $\mathrm{S} a^{\mathrm{n}}$ Pedro hacia su Poniente recostado bastante sobre el Norte se encuentra un monte de palmas dilatadissimo. Su largor (hablo de las palmas) por lo regular es de seis, ó siete varas muy derechas, y solidas, y sin labrar sirven en los edificios de alfagias hermosas; hacense tambien de sus cascaras Texas, de que en lugar de las de tierra cocidas usan para sus techos algunas Ciudades españolas de aquellas partes. Su corteza es muy dura, por lo que rompe muchas achas, y resiste mucho á la corruccion puesta en lugar humedo, y resguarda de las lluvias es impenetrable á la carcoma, ó polilla. Al norte del Pueblo de $\mathrm{S} a^{\mathrm{n}}$ Geronimo no muy distante se encuentra el lapacho, ó thajibo, preciosa madera, y con mucha abundancia á las veinte leguas de el en el lugar nombrado de las Capiguaras. Se cria muy grande, y tan solido, y fuerte que

\footnotetext{
${ }^{36}$ El término Sierpe (del latín serpens) es un sinónimo, actualmente en desuso o descontinuado, para referirse a una serpiente o culebra de gran tamaño.
} 
sirve para carretas, y carros de extraordinaria duracion sin gastar en ellos, ni en ellas una onza de hierro, ni verse en toda la $[14 \mathrm{v}]$ maquina un clavo, ni plancha la mas minima.

Minas, ni canteras no las ay en toda la costa Occidental del famoso Rio Paraná, ni en ella por muchísimas leguas se encuentra una piedra aun del tamaño de un huevo, pero si en su costa oriental, en donde abundan las piedras, y canteras. Montañas, ó cerros altos no se descubren, ni los ay en toda la parte Occidental del mencionado Rio Paraná por mas de ducientas leguas. Los ríos caudalosos son pocos en aquellas partes, y solo el sobredicho Rio Paraná, ó de la Plata es memorable, del que se encuentra ya mucho escrito. Ay abundancia de arroyos, que formados de las lluvias crecen ó menguan á su proporcion. Fuentes, ó manantiales con dificultad se hallan. El clima es cálido, y húmedo. El ibierno apenas se echa de ver en el, y rara vez se descubre un poco de escarcha. Segun la diversidad de terrenos, que en la America es grande, son los frutos, pero en el del Pueblo de $\mathrm{S} a^{\mathrm{n}}$ Geronimo, de $\mathrm{S} a^{\mathrm{n}}$ Pedro, y $\mathrm{S} a^{\mathrm{n}}$ Francisco Xavier, se coge por lo comun, y con mucha abundancia toda suerte de granos. El trigo solo por lo calido del sitio suele padecer no poco detrimento. En todos aquellos montes circunvecinos se halla á su tiempo porcion excesiva de grana, de que beneficiada con arte sale la perfecta cochinilla; miel rica, y de muchas especies, y cantidad notable de cera.

Desde el dia nueve de Febrero de 1765, en que como llevo dicho, entramos en el Inspin Chico, nos mantuvimos hasta el siete de Septiemb ${ }^{\text {re }}$ del mismo año, en que nos recogimos á nuestros ranchos de paja ya formados, haciendo el Padr $r^{\mathrm{e}}$ Florian Paucke, y yo á cuerpo descubierto en el sobredicho parage guerra á todas las inclemencias del tiempo sin otro defensivo para dormir, y descansar que un cuero de toro que sobre quatro palos estirado quebran[15] taba algo los rayos del sol, y nos defendia por la parte superior de las lluvias. Nuestra comida, nuestro cocinero, y nuestra cocina, no era otra que un poco de carne entonces flaca por la mudanza de terreno reciente de los animales, y continuo encierro de ellos, cocida en agua sin otro condimento, ni adherente con algunos mendrugos de pan, que contra la mohosidad tostados al horno haviamos llevado de San ${ }^{\text {ta }}$ Fee de Vera Cruz, nuestras proprias manos, y el campo libre. Nuestra Iglesia un altar portátil con unos ponchos de lana á manera de mantas, vestido proprio de los Indios, y al qual llaman ellos Quiapi, y aun de los españoles en aquellas partes, con que en lugar de capas metidos en la cabeza por medio de ellos, y descansando perfectamente sobre los dos hombros, y brazos, que del todo cubren, se defienden á caballo de las lluvias, y frios, que tendidos por sus costados, y parte superior sobre unas hastas de lanza la resguardaban del sol, y del viento. En ella se instruia en los principios, y fundamentos de nuestra ley para mas solemnidad los días de fiesta despues de la Missa á los Cathecumenos en los demas dias ordinarios era frequente la instruccion, observandose indispensablemente, desde que estuvimos entre ellos, el repetir los muchachos, y muchachones aun no casados ni á su modo, que dormian en las inmediaciones de nuestro alojamiento, todo el cathecismo ya en su lengua al mismo levantarnos por la mañana, al acabar nosotros la Missa hacian la misma diligencia todos, grandes, y pequeños de uno, y otro sexo, y á las dos de la tarde los muchachos, y muchachones de uno, y otro sexo en un lugar para esto destinado, y todos puestos de rodillas. A las oraciones concurrian todos, grandes, y 
Page. La relación sobre las costumbres y poblados de los mocovíes y abipones tutelados por jesuitas, escrita...

pequeños á rezar el rosario delante de una cruz, que á nuestro arribo alli imediatamente enarbolamos. A las animas, que tocábamos á su hora con una campanilla de mano, $[15 \mathrm{v}]$ rezaban otra vez en nuestra presencia, siempre de rodillas, los muchachos, y muchachones todos el cathecismo pidiendo por conclusion á la Virgen les concediesse felices noches, cantando todos á choros: Buenas noches nos deis Madre, Hija del Eterno Padre, Yo mucho me regozijo que tengáis á Dios por Hijo ${ }^{37}$. Esta misma santa obra hicieron al mismo tiempo las muchachas, y muchachonas, cantando de la misma suerte á choros en frente de sus alvergues luego que entre ellas se halló una capaz por su pericia de guiar á todas las demas.

Esta misma distribucion guardamos fundado ya el Pueblo, añadiendo solo á ella desde el nueve de setiembre del mismo año de 1765 el convocar, y juntar todas las mañanas, y tardes á los niños del Pueblo en la escuela, en la que se exercitaban dos horas á la mañana, y otras tantas á la tarde en imponerse con solidez en los rudimentos de nuestra santa fee y á los mas hábiles en aprender tambien á ayudar Missa. Salieron en este exercicio ya en la substancia, ya en el modo tan diestros algunos, que causaban admiracion á los mismos españoles mas despiertos, y pudieran competir en este punto con los mas bien instruidos entre estos. Con tan repetida, y quotidiana instruccion logramos antes de un año de nuestro ministerio entre estos pobres Mocobis tener el consuelo de ver casi cien de ellos por el Bautismo verdaderos hijos de Dios, y de la Iglesia, y mas de quince, quedando de mano á la multiplicidad de mujeres se hallaba por el sacramento del matrimonio, contentos con una sola. Entre los bautizados y casados in facie ecclesiae fueron tres caciques llamados: Pablo Lavagancaiquin, Santiago Cachingain, y Andres Dananitin, pero el quarto, principal Cacique, y fundador de el Pueblo no logró esta dicha por ciertos embarazos, y se llamaba Amaquin ${ }^{38}$.

Sin especial molestia nuestra concurrían quasi[16] diariamente, y á todas las horas señaladas con singular promptitud á las cosas de devocion. Se sujetaban, y daban sin trabajo nuestro sus hijos para el Bautismo. Facilitó mas en $\mathrm{S} a^{\mathrm{n}}$ Pedro esta no repugnancia lo que sucedio á un infiel bien instruido, pero tenaz en llevar adelante algunas de sus antiguas costumbres. Diole Dios una enfermedad grave, que poco á poco le puso á las puertas de la muerte, dexandole sin esperanza la mas minima en lo humano de vida. Exhortelo al dolor de sus antiguas maldades, y al proposito firme de no volver á ellas, y bien dispuesto le administré el Bautismo, dandole la vida de la gracia, y comunicandole palpablemente al mismo tiempo la del cuerpo. Fué tan notoria, y repentina esta sanidad del cuerpo, que á pocos dias de recibido el Bautismo andaba como todos los demas, y por todas partes el que poco antes se miraba tronco immoble, y retrato perfecto de la muerte. Advertida por notoria de los Indios esta maravillosa mutacion concurrian á nosotros pidiendo con muchas instancias el Bautismo para todo aquel que Infiel padecia alguna enfermedad en su cuerpo, y dando por razon esperanzados ser el medicina eficaz, como pocos dias antes lo havian echado de ver en el Infiel, de que acabamos de hablar. No se sujetaban, ni daban sus hijos para el Bautismo con tanta facilidad los Abipones.

\footnotetext{
${ }^{37}$ Subrayado por el autor.

${ }^{38}$ Ninguno de estos nombres reconocemos en la historiografía, desde Paucke a Furlong. El primero escribe que bautizaron en el primer año a 111 adultos y chicos (Paucke, 2010, p. 457).
} 
Enfermó en $\mathrm{S} a^{\mathrm{n}}$ Geronimo mortalmente un Indio infiel de los mas nobles, y guapos entre los de toda su nación, y azote que havia sido por sus hostilidades de los españoles. Accedieron con la noticia de su grave indisposicion los Padres Missioneros á disponerlo para el Bautismo, alejandole los motivos mas eficaces, y aproposito para conseguir su intento, entre los quales no dexaron de proponerle las atroces penas eternas del infierno. Siempre inflexible, y protervo el infiel respondia; que quería ir á ver lo que passaba en el infierno, donde estaban sus [16v] mayores, y que en caso de irle alli mal se tornaria. Se le repuso, ser imposible la vuelta, ó huida una vez entrado alli. Pero llevando adelante temerariamente la suya satisfizo diciendo: esperare que el Diablo se duerma, y entonces me escapare. Se le replicó todavia con que el Diablo nunca duerme; á que siempre inexorablemente respondio: por mas vigilancia del Diablo me podré escapar de el, como me fui escapado, y no pocas veces de los españoles por mas cuidadosos que han andado para lo contrario. Antes de morir suplicó á los Padres huviessen de el compassion no bautizandole despues de muerto. Llamabase este infeliz Quebachi ${ }^{39}$.

Con otro caso, y en el mismo Pueblo mostró Dios la eficacia del Bautismo, y lo que se complacio en el. Adolecio de un accidente repentino una muchachona infiel de buenas costumbres, y bien instalada, que quedando en fuerza del achaque su cuerpo como un tronco tendido sobre un cuero, vino uno de los Padres Missioneros, que á la entrada de su pobre choza de paja la empezó á hablar sobre el Bautismo. Cosa rara! Que al mismo empezarla á hablar el Missionero sobre este punto del sacramento e intención de recibirlo, se vio con espanto de todos los presentes aquel cuerpo del todo postrado retirándose del Padre, é huir de el saliendose de la casita por un ahujero de ella. Observado del Padre, y conociendo la causa de tan extraordinario efecto la baño immediatemen ${ }^{\text {te }}$ con las aguas saludables del Bautismo, con lo que quedó quieta, é inmoble, sanando dentro de algun tiempo totalmente de su indisposicion.

No poco ayudó á la repugnancia de recibir Bautismo en $\mathrm{S} \mathrm{a}^{\mathrm{n}}$ Geronimo la predica de un indio entre ellos medico, que de casa en casa peroraba ser falso que los Padres decían de el Bautismo, dando por razon haver el subido al Cielo, y registradole todo no havia encontrado en el muchacho alguno, ó persona de los que los mismos Padres [17] havian bautizado, y que luego immediatamente havian muerto.

No solo atendimos entre estos pobres immediatamente al bien de sus almas, era también necessario por ellas mismas todo nuestro cuidado en orden á sus cuerpos: por lo que era preciso proveerlos de comida, vestido, y otras cosas necesarias; para lo $\mathrm{q} u^{\mathrm{e}}$ se les instruia, y muchas veces con nuestras proprias manos ya en arar, ya en cabar la tierra, y en todos los modos de cultivarla, ya tambien en varias artes mecánicas como carpintería. Eramos nosotros entre ellos no solo médicos de sus almas, sino tambien de sus cuerpos, por lo que nos era forzoso traer frequentemente entre mannos algun otro mamotreto de remedios, que no pudiendo dañar pudiessen aprovechar, y á estas medicinas se les suele llamar vulgarmente remedios caseros.

\footnotetext{
${ }^{39}$ El P. Paucke menciona un Lucas Quebachin, que no sería, pues al tener el nombre Lucas fue bautizado (Paucke, 2010, p. 448).
} 
Page. La relación sobre las costumbres y poblados de los mocovíes y abipones tutelados por jesuitas, escrita...

De cinco en cinco dias á los principios, hasta que comenzaron á recoger el fruto de sus sembrados, repartiamos con este orden carne á todos: á cada cinco familias, en que entraban tambien las viudas, se les daba una baca, ó novillo grande, por lo que se consumían en este corto tiempo, siendo del Pueblo aun tan pequeño, dieciseis, ó dieciocho cabezas con las que se mataban para nuestro gasto; despues de seis en seis días. Toda su comida, y todo su pan, con el de muchos españoles en aquellas partes, se reduce, y encierra en sola la carne. Todos los Domingos se daba á las mugeres su porcioncita de sal, y á los hombres, y muchachones tabaco de hoja, y hierba, que se dice, del Paraguay, como tambien los Martes, y Jueves solamente á estos ultimos. La hierba del Paraguay en todas sus maniobras, ó trabajos se les subministraba, porque de lo contrario no havia trabajo. A mas de estos referidos gastos indefectibles era forzoso de quando en quando socorrerlos de cuchillos, de tixeras, de ahujas, de rosarios, de abalorios, de gorros colorados de que mucho gustan, y, en una palabra, de todo lo preciso para una vida mas civil, y menos barbara que la $[17 \mathrm{v}]$ suya antigua, porque ellos de todo ello carecen, y son incapaces de gobernarse economicamente por si en orden á adquirirlo, y conservarlo largo tiempo.

Desde el mes de septiembre de 1763 en que llegaron la primera vez estos nuevos Mocobis al Pueblo de $\mathrm{S} a^{\mathrm{n}}$ Xavier hasta el primero de mayo de 1765 en que con real authoridad se hicieron dueños del sitio de $\mathrm{S} a^{\mathrm{n}}$ Pedro se mantuvieron en un todo á expensas de los moradores de sobredicho Pueblo de $\mathrm{S} a^{\mathrm{n}}$ Xavier, que gustosos caritativamente dividían sus cosas con sus pobres paysanos, amigos, y parientes. Desde el dia pues primero de Mayo del mencionado año de 1765 empezaron á comer de las limosnas, que con mucha charidad les hicieron los señores santafecinos, que se estendieron á mil, y quinientas bacas, de las que dio trecientas nuestro Colegio de San ${ }^{\text {ta }}$ Fee de Vera Cruz, á quatrocientos pesos fuertes en plata con algunas menudencias para adornar la Iglesia, y erramientas para las maniobras. El Señor theniente $\mathrm{D} o^{\mathrm{n}}$ Francisco Antonio de Vera, y Muxica cedio, y assi lo cumplio, en bien de aquellos pobres cathecumenos por todo el tiempo de su oficio ciento, y quarenta pesos duros, que anualmente por razon de su empleo de cierto ramo le tocaban. Su Reverenci ${ }^{\mathrm{a}}$ el Padr ${ }^{\mathrm{e}}$ Provincial Pedro Juan Andreu diligenció con extraordinarias diligencias, ó fatigas, y espensas quantiosas de plata, que el año á 1766 entrassen en el Pueblo de $\mathrm{S} a^{\text {n }}$ Pedro de los diezmos de la Ciudad de $\mathrm{S} a n^{\text {ta }}$ Fee de Vera Cruz del año de 1765 son mil cabezas bacunas, y dos mil ovejunas con algunas potrancas, y potrillos, disponiendo juntamente, como lo logró, que los mismos diezmos del año siguiente de 1766 se rematassen tambien para el Pueblo de $\mathrm{S} a^{\mathrm{n}}$ Pedro y se remataron en cinco mil, y tantos pesos fuertes, [18] entrando tambien todo el diezmo de mulas, potros, y potrancas. Estos mismos diezmos de $\mathrm{S} a n^{\text {ta }}$ Fee de Vera Cruz, y toda su jurisdiccion en tiempo de las guerras con los Indios, y antes de fundarse los referidos Pueblos Mocobis y Abipones con dificultad se remataban en trecientos, ó quatrocientos pesos fuetes. El año de 1744 ó 45 fundado ya el Pueblo de $\mathrm{Sa}^{\mathrm{n}}$ Francis ${ }^{\mathrm{co}}$ Xavier se remataron a setecientos pesos con admiracion de todos los practicos, que creieron perderse del todo el postor. Proveyó tambien su Reverenci ${ }^{\mathrm{a}}$ el dicho Padr ${ }^{\mathrm{e}}$ Provincia ${ }^{\mathrm{l}}$ la capilla del Pueblo de $\mathrm{S} a^{\mathrm{n}}$ Pedro de ornamentos, caliz, campana grande y de todo lo demas necessario. No dexaron por su charidad socorriendo á la dicha Capilla, de tener lugar en 
tan santa obra algunos Padres Rectores de la Provincia, entre los quales son dignos de individual memoria el Padre Manuel Querini, del Maximo de Cordoba del Tucumán, y el $\mathrm{P} a d r^{\mathrm{e}}$ Joseph Brigniel, de el de San ${ }^{\text {ta }}$ Fee de Vera Cruz, el excelentisi ${ }^{\text {mo }}$ Señor Governador de Buenos Ayres Do $o^{\mathrm{n}}$ Pedro de Zevallos, aunque tan embarazado en aquellos tiempos con extraordinarios negocios del Rea ${ }^{1}$ servicio, volvio miseriocordiosamente los ojos al Pueblo de $\mathrm{S} a^{\mathrm{n}}$ Pedro, de que vamos hablando, ofreciendole de sus bienes provados mil bacas, hubiera echo en bien de el, si las circunstancias no lo huviessen estorbado, otros no inferiores oficios de su mucha charidad para con los pobres.

Se ha advertido por los Padres Missioneros mas solicitos, y observadores sobre este punto no hallarse entre las dos celebres naciones Mocobi, y Abipona deidad alguna, á quien presten como a tal el mas minimo culto. Creen que partidos de esta vida viven en la otra, y en [18v] ella exercen las mismas operaciones que en esta; por lo q $u^{\mathrm{e}}$ acostumbran en su infidelidad al espirar hacerse matar los mexores caballos, para tener, según ellos dicen, con que en ella andar á caballos, correr animales, y buscar su comida. Sus armas son una lanza con una hasta larga tres, ó quatro varas, un mazo de flechas crecidos, una macana, que es un palo muy duro, y pesado, y suele por lo ordinario ser de palo santo $\mathrm{q} u^{\mathrm{e}}$ llaman los españoles, con una porra al remate. El largo de esta macana es como del codo á la mano poco mas: algunos dardos arrojadizos, con la contusion de cuyas puntas muy fuertes, y á manera de bayonetas no esquinadas sacan de su á qualquier contrario. En las guerras contra los españoles no acometen todos juntos, ni por lo común pelean con ellos cuerpo á cuerpo, y á las claras. Fatiganlos en tropillas de treinta, ó quarenta en ademan de acometer, presentandoseles á lo lexos á su vista, y por muchas partes, y no los acometen sin estar seguros del lance, y entre tanto se emplean tambien en hurtarles á los mismos españoles, en que son muy diestros, sus caballos, y dexarlos á pie en aquellos campos tan dilatados. Para conseguir otros hurtos se valen entre otros del ardid de introducir, quan menos se piensa, y sin advertirse, entre la caballada española un caballo de ellos con un cuero de tigre encima, con cuyo olor atemorizada, y posseida de miedo echa á huir como caballos desbocados sin poco contener, ó del de passar á toda furia con un cuero arrastrando un Indio á caballo por las inmediaciones, donde saben está la sobredicha caballada. En las peleas entre si no suelen dividirse, o formarse en trozos para acometer, y por lo comun pelean echado el pie en tierra, y desnudos de medio cuerpo abajo para estar mas libres para las acciones, y en ellas de medio arriba lo adornan con [19] con lo mejor que tienen, como tambien sus caballos; y los Caciques, y principales, ó guapos su cabeza con un gorro á manera de turbante, en que por medio de peregrinas, y hermosas plumas muestran las muertes, que en toda su vida han cometido en sus contrarios. Su vestido ordinario en los hombres es una piel de nutrias, ó de gamas, que á manera de manta doblada, y atada por una punta se la meten por la cabeza por la parte superior del hombro derecho, é inferior del izquierdo, con q $u^{\mathrm{e}}$ cubren la caxa, ó lo mas de su cuerpo, dexando siempre desnudos, y libres los brazos. En las mujeres es la misma piel doblada, que ceñida por medio del cuerpo cubren toda su parte inferior de el, y dexan al ayre toda la superior. Suelen algunas veces cubrir el medio cuerpo arriba con otra piel, que á modo de mantilla, ó capotillo de muger europea ponen á los hombros. 
Page. La relación sobre las costumbres y poblados de los mocovíes y abipones tutelados por jesuitas, escrita...

Sus viudas á mas del referido vestido cubren su cabeza, y cara con un velo claro como red basta, y ordinaria.

En sus casamientos interviene verdadero contrato natural. Compran á la muger por dos, ó quatro caballos con su silla, ó lomillos, que es el aparejo de aquellas tierras, una lanza, y á veces alguna otra cosa, pero son libres para rescindir, quando quieren, el contrato, volviendo la muger á sus Padres, ó parientes, y tienen derecho á recobrar lo, que dieron por ella, si aun está en ser. Si durante el referido contrato tuvieron hijos, al disolverse siguen, y no se apartan de su Madre, sin hacer caso de su Padre, á quien miran por lo comun como estraño. El adulterio entre ellos es abominable, y con dificultad se podrá referir caso, ó circunstancias de haverlo cometido alguno de los individuos de estas dos naciones. Sus borracheras en tiempo de algarroba, y de la miel son quotidianas. Hacen bebida de el agua de algarroba, ó de la miel bien fermentada. Quando ya están calientes, les escon[19v]den las Indias todas las armas, despojándolos aun de los cuchillos, que traen necessariamente consigo.

Tienen sus Medicos que por la operacion en curar se llaman chupadores. Luego que alguno enferma, acude el chupador, y para las mujeres ay también chupadoras, y aplicando este la boca á la parte dolorida, sea la que fuese, comienza á chupar, hacer gestos, y fingir que sale el mal. Si muere el enfermo, nada le pagan, y, si acaso se han adelantado la paga, la vuelven luego. Son estos Medicos chupadores, ó echiceros, que tambien tienen este nombre gente, que no pudiendo por las armas tener entre los suyos lugar, se valen del embuste, y del enredo para hacerse de ellos respetar. El mayor embarazo para la Fee son ellos, y las mujeres casadas, por temer aquellos que los Missioneros descubriendo sus embustes los dexen sin reputacion, y aquellas ciertas de su oposicion á la multiplicidad de mugeres viven rezelosas cada una por su parte de ser repudiadas. Afectan tener en su mano la salud, y enfermedad. Tuvo en cierta ocasión en el Pueblo de $\mathrm{S} a^{\mathrm{n}}$ Geronimo el Padr ${ }^{\mathrm{e}}$ Cura de el Francis ${ }^{\mathrm{co}} \mathrm{Nabalon}^{40}$ un grave accidente colico, que lo postró en la cama debido por un chupador empezó á predicar por el Pueblo ser el el origen del quebranto aquel en la salud del Padre en venganza de no sé que cuento que dias antes havia tenido con el referido Padre A[ilegible]bo de algunos dias fingiendo compassion, y que ya havia rompido, y obrado la naturaleza, se metia en la casa de su Cura, y Missionero el buen chupador diciendo venia á curarlo. Preguntole el Padre el modo y sin decir palabra enderezasse á la cama, en que estaba tendido en accion de querer subir, y descansar sobre el con todo su cuerpo. Entonces el Padre anim[ilegible] le dixo con eficacia; se fuesse de alli que era un embustero, engañador, que no queria ser curado de el el buen Medico sin alterarse se retiró muy de espacio, y al salir del aposento, diciendo, aunque no quieras te he de curar, sopló unas quantas veces como saludador, y se fué. Levantose el Padre de la cama luego, y empezó á andar

40 El P. Francisco Navalón nació en Olmedo, Valladolid, el $1^{\circ}$ de marzo de 1716, ingresó a la provincia del Paraguay en 1732, arribando a Buenos Aires dos años después en la expedición del P. Antonio Machoni. Profesó su cuarto voto en Santa Fe en 1750 y la expulsión lo sorprendió en la reducción de San Jerónimo que fundó con el P. Burgés, muriendo en Faenza en 1783 (Storni, 1980, p. 197). Fue misionero entre mocovíes y abipones. Los registros navieros informan que era "blanco, ojos negros y un poco belfo" (Furlong, 1938, p. 180) 
como antes por la casa, y Pueblo: observado del echicero, ó chupador publicó andando de casa en casa por toda la poblacion haver el movido de lastima dado salud á su Cura. El idioma Mocobi es sumamente (lo propio digo del Abipon) dificultoso en si, y por sus circunstancias, por ser diferente, ó diverso el lenguaje de los nobles, y Caciques del de los plebeyos; y el de las mugeres de el de los hombres.

Son los Mocobis, y Abipones gente de á caballo, y libre, y por tanto no tan faciles de sujetar. Son de ordinario altos, y bien formados, de color algo atezados, pero ay entre ellos varios blancos, y de pelo rubio. Son amigos de la guerra, cuyos trabajos sufren gustosos con tenacidad, y constancia. Son en extremo vengativos, y no dormiran, ni descansaran, aunque sea por muchos años, hasta haver en su contrario saciado esta su passion.

Entre los Mocobis, y en el Pueblo de $\mathrm{S}^{\mathrm{n}}$ Pedro trabaxando en utilidad de sus moradores nos hallamos el Padre Pedro Polo, ó Powlo ${ }^{41}$, natural de Londres en Inglaterra, y yo el año de 1767 quando extrañados efectivamente del Colegio de San ${ }^{\text {ta }}$ Fee de Vera Cruz los Padres Jesuitas, puso en el Pueblo de $\mathrm{S} a^{\mathrm{n}}$ Xavier por medio de $\mathrm{D} o^{\mathrm{n}}$ Bernardo Garmendia ${ }^{42}$, ó Andinito por otro nombre el theniente de dicha Ciudad de San ${ }^{\text {ta }}$ Fee de Vera Cruz Don Juachin Masiel $^{43}$ el 17 de Julio de [20v] 1767 una carta circular á todos los tres referidos Pueblos y llegó a $\mathrm{S} a^{\mathrm{n}}$ Pedro el 18 y á $\mathrm{S} a^{\mathrm{n}}$ Geronimo el 20 del mismo, y en formales terminos decía assi: "Haviendo su Magestad estrañado de todos sus dominios á los Padres de la Compañia, como se executó en esta Ciudad el 13 del corriente, prevengo á Vuestra Paternidad no haga novedad en su ministerio respeto á haver venido el orden, para que se execute con los sujetos de Colegios, y no con los Padres Curas de Reducciones".

El orden de su excelentísi ${ }^{\text {mo }}$ Governador D $o^{\mathrm{n}}$ Francisco Paula Bucareli, y Ursua fue para el extrañamiento, y aun mismo tiempo de todos, pero el recelo de perder los Santafecinos sus haciendas, muchos sus vidas, y destruir su Ciudad obligó al teniente á tomar tiempo para atraer á los Indios á la pacifica salida de sus Padres Curas Jesuitas. Los Caciques de $\mathrm{S} a^{\mathrm{n}}$ Xavier con tan extraordinaria novedad fueron al punto á la Ciudad de $\mathrm{S} a n^{\text {ta }}$ Fee de Vera Cruz en compañía del portador de la dicha carta que los induxo (al parecer por instruccion secreta) á que se avistassen luego con el theniente. En San ${ }^{\text {ta }}$ Fee de Vera Cruz á su llegada se les suministró en abundancia agua ardiente, y algun otro

${ }^{41}$ El P. Poule nació en Londres el 12 de noviembre de 1728, ingresando a la Compañía de Jesús del Paraguay en 1748. Sus primeros votos los profesó dos años después y sus últimos en Santa Fe en 1763. La expulsión lo sorprendió en San Pedro, muriendo en Londres el 9 de enero de 1793 (Storni, 1980, 226). Sabemos que su incorporación a la Compañía de Jesús se dio al ser parte de la tripulación de un barco británico que se incendió frente a Colonia de Sacramento (Furlong, 1938a, p. 180).

${ }^{42}$ Bernardo Garmendia era Maestre Mayor Conservador y Director de Postas y Correos de la carrera de Santa Fe al Paraguay, desde Buenos Aires y Sargento mayor de la frontera y cuerpo de milicias de la Ciudad de Santa Fe y capitán de la Compañía de Blandengues de la misma jurisdicción.

${ }^{43}$ Joaquín Maciel nació en Santa Fe en 1729 y murió en 1780. Fue nombrado primero alcalde de segundo voto en 1755 y luego teniente de gobernador de Santa Fe desde 1766 hasta 1771. A su pesar fue designado por el gobernador rioplatense Francisco de Paula Bucarelli como comisionado para ejecutar la expulsión de los jesuitas en su jurisdicción. Posteriormente tuvo que afrontar con éxito la rebelión de los pehuelches y trasladarse a Cuyo. A su regreso fue acusado de beneficiar a los jesuitas y sus enemigos lograron destituirlo. 
Page. La relación sobre las costumbres y poblados de los mocovíes y abipones tutelados por jesuitas, escrita...

licor, de que gustan mucho los Indios, para que viniessen con este cebo contentos en lo que se les pediria. Calientes ya, y alguno otro beodo los presentaron al mencionado theniente á quien, despues de recitada una larga arenga, sobre las conveniencias de los referidos Indios en la salida de los Padres de sus Pueblos, le propuso entre otros inconvenientes en ella un Cacique aun no borracho este: idos nuestros Padres, quien nos ha de enseñar, y confesar? La lengua es muy difícil, y los clérigos señalados son los uno crecidos ya en edad, y no se aplicarán como nuestros Padres al estudio de ella. No ay que reparar en esso, dixo el theniente y en orden á la confession añadio bastar para el perdon de los pecados postrarse con dolor á los pies del confessor, y proferir este la formula de la absolucion. Dixo entonces el Cacique borracho, pues, si assi es, saldrán los Padres, y se acabó la session [21] Partidos ya al campo los caciques, y vuelto en si el Cacique borracho se vio sobrecogido de una profunda tristeza, y verguenza á la consideracion clara de lo que havia echo, y mas al ver á los indios, y concaciques alborotados contra el; por lo que sin detenerse en $\mathrm{S} a^{\mathrm{n}}$ Xavier se enderezó sin poderle contener á los montes con su gente para no salir de ellos hasta ver de vuelta en los Pueblos á sus queridos Padres.

Los Indios de $\mathrm{S}^{\mathrm{n}}$ Pedro á la novedad de partirse sus Padres Doctrineros nos dexaron en dos ocasiones solos, solos, solos, y al Pueblo sin mas alma racional que al Padre Pedro Polo, ó Powlo, y á mi. Aplicadas todas las posibles diligencias los volvimos, y nos acompañaron como antes. En el Pueblo de $\mathrm{S} a^{\mathrm{n}}$ Geronimo hizo extraordinaria impression la noticia, y con especialidad en Joseph Benavides, celebre Cacique, que salio casi de si de sentimiento, y tomara las armas contra el español, si los Padres sin omitir diligencia no lo estorvaran. Desde que se supo la novedad de nuestro destierro en aquellos Pueblos, todo en ellos era confusion, y alboroto sin dexarnos parar, comer, ni dormir, No se apartaban de nosotros de dia, ni de noche, y en esta demonitracion se señaló con especialidad Joseph Benevides, quien decía á los Padres tuviessen paciencia, porque cierto de su ausencia queria tener aquellos pocos días el consuelo de verlos, y mirarlos, añadiendo que si fuera mas mozo los acompañaria personalmente hasta su destino. Querian llevarnos consigo á los montes unos, otros querian exonerse a nuestra salida, y otros desfogando su colera en amenazar á la Ciudad de San ${ }^{\text {ta }}$ Fee de Vera Cruz, y á todos los españoles.

Entre estas inquietudes llegamos al once de Agosto, en que intimó en $\mathrm{S} a^{\mathrm{n}}$ Xavier el real Decreto de nuestro exterminio el comissionado $\mathrm{D} o^{\mathrm{n}}$ Pedro Miura ${ }^{44}$, vecino de $S a n^{\text {ta }}$ Fee de Vera Cruz, é hijo en España del Reyno de Navarra, y al diecisiete, ó dieciocho, en que se hizo la misma diligencia en $\mathrm{S} a^{\mathrm{n}}$ Pedro, y al veinte y uno, ó veinte, y dos, en que se executó [21v] lo mismo en $\mathrm{S} a^{\mathrm{n}}$ Geronimo, acudiendo personalmente á todas estas diligencias, y en todas partes dicho Señor Comissionado Puso en nuestro lugar en el Pueblo de $\mathrm{S} a^{\mathrm{n}}$ Francis $i{ }^{\mathrm{co}}$ Xavier al $\mathrm{D} o c t^{\mathrm{or}} \mathrm{D} o^{\mathrm{n}}$ Mathias Ziburu ${ }^{45}$, en el de $\mathrm{S} a^{\mathrm{n}}$

\footnotetext{
${ }^{44}$ Pedro Mihura, notario del Santo Oficio de la Inquisición (+1776), fue designado fiscal de la Junta Municipal de Temporalidad el 2 de agosto y cinco días después, Fermín de Echagüe y Andía como Procurador, presentó los resultados de una investigación que conduce rápidamente a la suspensión de Maciel en sus funciones. En 1775 Mihura es designado para el parcelamiento de las propiedades rurales de los jesuitas a fines de rematarlas

${ }^{45}$ El sacerdote Matías de Ziburu fue visitador eclesiástico de Corrientes en 1757 por encargo del
} 
Pedro al Maestro Do $o^{\mathrm{n}}$ Francisco Reyes, y en $\mathrm{S} a^{\mathrm{n}}$ Geronimo al Maestro Do $o^{\mathrm{n}}$ Vicente Troncoso ${ }^{46}$, dandoles al mismo tiempo una instruccion del Señ ${ }^{\text {or }}$ Obispo de Buenos Ayres $\mathrm{D} o^{\mathrm{n}}$ Manuel Antonio de la Torre, aprobada por el excelentísi ${ }^{\mathrm{mo}}$ Governador Bucareli, sobre el modo de haverse con los Indios, y en ella en expresos terminos se les ordenaba, que en todo practicassen la conducta, que havian observado los Padres curas Jesuitas ya en el fuero interno, ya en el externo. Dicho Señ ${ }^{\text {or }}$ Miura se portó en todo momento con mucho zelo hacia el servicio de Dios, y del rey. Hizo de su parte un exacto inventario de las cosas de los tres Pueblos: exhortó á los Indios á la obediencia de Dios, y del Rey, por lo que quedaron menos disgustados de lo que sino quedarian. Fué en su compañia el precitado $\mathrm{D} o^{\mathrm{n}}$ Bernardo Garmendia, en cuyo trato era necessaria toda reserva.

Quedaron en el Pueblo de $\mathrm{S} a^{\mathrm{n}}$ Xavier como veinte, ó veinte un mil bacas, de ovejas como tres, ó quatro mil, de mulas ya de tres años como quatrocientas sin las de menos edad, que eran muchas: una yeguada muy crecida, y la caballada llegando á quinientos, ó seiscientos: bastante boyada, cinco, ó seis carretas para el tragin de las cosas: dos embarcaciones, una grande, y otra pequeña; una casa de cinco aposentos de tapia con techo de texa: una capilla grande de adobes, ó ladrillos no cocidos con su techo de paja, pero con materiales muchos, que se iban juntando para fabricar de nuevo una muy grande de ladrillo cocido toda con techo de texa. En dicha capilla havia bastantes ornamentos, algunos buenos, y entre ellos uno nuevo con su capa de choro, y paño de facistol de rica persiana: bastante ropa blanca, suficiente sin escasez para dos altares; havia unos tres, ó cuatro calices de plata sobredorados con sus patenas correspondientes: tres, ó quatro pares de vinagreras [22] de plata con sus platillos de lo mismo: un copon de plata; chrismeras dos fuegos, ó tres tambien de plata: una capa negra de choro, y dos de color: dos, ó tres campanas grandes. Muchas otras cosas havia mas, pero no las noté con bastante individualidad, por no haver jamas estado yo residente en el sobredicho Pueblo. Quedó en el Pueblo de $\mathrm{S} a^{\mathrm{n}}$ Xavier una huerta grande con diversidad de plantas, como higueras y muchas, crecido duraznal, naranjal dulce, y agrio, limonal real, manzanal, sidral, toronjal, granados, un parral, y alna otra planta de piñas, y mucha abundancia en ella de todas suertes de hortalizas. En lugar separado un trigal crecido, y dos algodonales grandes.

Debia este Pueblo al oficio de Missiones de la Ciudad de San ${ }^{\text {ta }}$ Fee de Vera Cruz diecisiete mil pesos fuerte, y estos entendere siempre que en adelante diga pesos, bien que con los efectos, que tenia ya en dicho oficio, ó procuraduria, los que tenia ya para embiar á el, y los sínodos de muchos años no pagados baxaria la deuda á once mil. Componiasse este Pueblo de novecientas almas, todas christianas, y muchas de exemplar proceder. En el Pueblo de $\mathrm{S} a^{\mathrm{n}}$ Pedro se inventariaron cinco mil, y tantas cabezas de ganado vacuno,

obispo Marcellano y Agramont. En la ocasión fundó el pueblo de Caá Catí. Luego de pasar siete meses en la reducción de San Francisco Javier, Ziburo pidió ser exonerado argumentando problemas de salud (Moriconi, 2014, p. 35).

${ }^{46}$ Ambos sacerdotes no tuvieron suerte, los abipones de San Jerónimo con los de Corrientes atacaron las reducciones de San Pedro y San Francisco Javier. Reyes y Troncoso pidieron ayuda al teniente de gobernador Vicente Zavala. Las luchas continuaron y pronto los sacerdotes fueron reemplazados una y otra vez, en tanto los pobladores huían al Chaco, hasta que los pueblos se desvanecieron (Furlong, 1938, pp. 200-204). 
Page. La relación sobre las costumbres y poblados de los mocovíes y abipones tutelados por jesuitas, escrita...

ochocientas, ó mas de ovejuno, algunas yeguas, y caballos: tres aposentos de embarrado, ó de pared, que en aquellas tierras llaman, francesa ${ }^{47}$ con su techo de paja: una capilla de ocho varas escasas de ancho, y veinte de largo de adobes, y techo de paja: una huerta muy grande poblada ya toda de mucha, y diversa arboleda, la misma havia en ella que en la de $\mathrm{S} a^{\mathrm{n}}$ Xavier, dos algodonales muy crecidos á sus lados: noventa, y ocho arrobas de algodon muy especial ya cogido, que se vende en aquellas partes la arroba quando menos á dos pesos, y medio; y otras varias cosas, que omito. En la Capilla quedaron lo menos diez ornamentos muy buenos, seis blancos, uno colorado, otro [22v] negro, otro verde, y otro morado con una capa de choro blanca: cinco albas ricas, tres hermosos manteles largos para el altar, y de la mas ropa blanca mucha, y buena; unas vinageras de plata con su platillo de lo mismo: un caliz de plata sobredorado con su patena de la misma suerte: una caxita de plata para llevar al cuello el Señor á los enfermos, y su coponcillo tambien de plata, dos punteros de plata para las chrismeras, y una campana grande. En todo esto, ni en las demas cosas del Pueblo, como ni en su fabrica no havia aun gastado nuestro Monarca un quarto. Debia este Pueblo ochocientos pesos al Oficio, ó Procuraduria de Missiones de San ${ }^{\text {ta }}$ Fee de Vera Cruz, pero también nos debía el Rey nuestro Señor los synodos de dos años, y tres meses, que á razon de quatrocientos pesos al año por los dos Missioneros eran novecientos. Debianos tambien quinientos pesos, que para la campana, y ornamento ordena su Magesta en su recopilacion de Indias se de á cada nueva fundacion de Indios. Con lo que, y muchos efectos, que teniamos en ser se cubria con ventajas la deuda. El numero de almas del dicho Pueblo de $\mathrm{S} a^{\mathrm{n}}$ Pedro era á la razon de nuest $t^{\text {ro }}$ destierro ciento, y quarenta, ó cinquenta, aunque otras veces era maior, como sucede en toda nueva poblacion de indios hasta que assienten el pie, y á las veces eran trecientas. Estaban ya para venir á $\mathrm{S} a^{\text {n }}$ Pedro con animo de establecerse en el unas ochocientas, ó novecientas almas Mocobis. En el referido Pueblo de $\mathrm{S} a^{\mathrm{n}}$ Pedro havian de entrar aquel año de 1767 seis mil cabezas de ganado bacuno, y tres mil de ovejuno de los [23] diezmos de San ${ }^{\text {ta }}$ Fee de Vera Cruz arrendados á este fin.

Havia en el Pueblo de $\mathrm{S} a^{\mathrm{n}}$ Geronimo tres, ó quatro mil cabezas de ganado bacuno, y dos, ó tres mil de ovejuno: tres, ó quatro aposentos de pared francesa con el techo de paja: una capilla de lo mismo, y en ella bastantes ornamentos buenos, ropa blanca mucha y buena, dos calices de plata sobredorados con sus patentes correspondientes; un altar portátil muy bueno; dos, ó tres pares de vinageras con sus platillos tambien de plata; una huerta especial adornada de toda la arboleda referida en los dos antecedentes nombrados Pueblos, pero por su extraordinario cultivo era singular, y en ella se encontraba mucha, y rica hortaliza. Debia este Pueblo al oficio tambien de Missiones de la Ciudad de San ${ }^{\text {ta }}$ Fee de Vera Cruz como dos ó tres mil pesos, que con los sínodos, que no se le havian abonado en algunos años, y efectos, que tenia en ser, pagaba la maior parte de esta deuda. El numero de almas en este Pueblo christianas eran quinientas noventa, y tres, y cathecumenos ducientas treinta, que por todas son ochocientas veinte, y tres. Cuidaban de este Pueblo al tiempo de nuestro arresto los Padres Francisco Nabalon, y Josph

${ }^{47}$ El P. Paucke ilustra y describe el sistema constructivo. 
Lehmann, de el de $\mathrm{S} a^{\mathrm{n}}$ Xavier los Padres Florian Paucke, y Ramon Termeyer ${ }^{48}$, hijo de Cadiz, y del de $\mathrm{S}^{\mathrm{n}}$ Pedro los Padres Pedro Polo, ó Powlu, y yo Antonio de Bustillo, natural de ugar de Aloños del Valle de Carriedo en el Obispado de Santander.

El dia veinte, y cinco de Agosto del mismo año de 1767 salieron de $\mathrm{S} a^{\mathrm{n}}$ Geronimo en compañia del [23v] referido comissionado $\mathrm{D} o^{\mathrm{n}}$ Pedro Miura los mencionados Padres Francis ${ }^{\mathrm{co}}$ Nabalon, y Joseph Lehmann: llegaron a $\mathrm{S} a^{\mathrm{n}}$ Pedro el veinte, y ocho por la mañana, y por la tarde del mismo dia veinte, y ocho todos juntos caminamos á $\mathrm{S} a^{\mathrm{n}}$ Xavier, en donde nos agregamos á los Padres de aquel Pueblo. Antes de salir los Padres de $\mathrm{S}^{\mathrm{n}}$ Geronimo se confessaron los Indios por la ultima vez, según ellos decian, y entre ellos Joseph Benavides, llenos, ó cubiertos todos de confusion, y heridos de solido arrepentimiento de sus culpas; y lo mismo hicieron con muchas instancias los de $\mathrm{S} a^{\mathrm{n}}$ Pedro, y $\mathrm{S} a^{\mathrm{n}}$ Xavier antes de separarse de sus queridos Padres, pero con tales demostraciones de ternura, $\mathrm{q} u^{\mathrm{e}}$ movian á compassion á todos, y mas á aquellos, que en christo los havian engendrado por la gracia y los obligaban á derramar sin libertad abundancia de lagrimas. El segundo de Septiembre del mismo año salimos todos los Padres de los dichos tres Pueblos, y el Señ ${ }^{\text {or }}$ Comissionado Do $o^{\mathrm{n}}$ Pedro Miura del Pueblo de $\mathrm{S} a^{\mathrm{n}}$ Francis ${ }^{\mathrm{co}}$ Xavier en compañia de muchos Indios, y del Cacique Domingo Nevegdanac ${ }^{49}$, que supo poder contener, y sin creer lo que miraban, nos seguían atonitos. Llegamos á la Ciudad de San ${ }^{\text {ta }}$ Fee de Vera Cruz el dia cinco del mismo mes de Septiembre, y passamos por un lado sin entrar en ella, vadeando el rio, ó Salado por el passo conocido de Ziburu, y arribamos á San to Thome, hacienda, que fue de nuest ${ }^{\text {ro }}$ Colegio de $\mathrm{San}^{\text {ta }}$ Fee de Vera Cruz, el dia seis, y distante de dicha Ciudad como un poco mas de quarto de legua.

Aqui nos estuvimos en nuestras carretas hasta el dia ocho sin poder entrar en la hacienda, habitar en sus [24] aposentos, ni decir Missa en su capilla. En este tiempo se incorporaron con nosotros el Padr $r^{\mathrm{e}}$ Juan Francis ${ }^{\mathrm{co}}$ Ortiz de Ocampo ${ }^{50}$, que pasando

${ }^{48}$ El P. Termeyer nació en Cádiz el 2 de febrero de 1737, ingresando en la provincia andaluza en 1755. Dos años después profesó sus primeros votos en Sevilla, donde seis años después el obispo auxiliar Domingo Pérez de Rivera le confirió el sacerdocio. Llegó a Buenos Aires en la última expedición jesuita, en la que estaban al frente los PP. Simón Bailina y Juan de Escandón. La expulsión lo sorprendió en San Javier y murió en 1814 (Storni, 1980, 282). Sabemos también que este hijo de alemanes vivió en Milán y Génova. Incluso en Faenza fue matemático y aficionado a la óptica, contando desde microscopio hasta telescopio con los que hizo importantes descubrimientos que plasmó en su libro "Opusculi scientifici...", publicado en cinco tomos en Milán entre 1807 y 1809, donde también incluyó noticias históricas de los jesuitas del Paraguay. Entre otras cosas introdujo en el Río de la Plata el gusano de seda pero trabajó con arañas, llegando a fabricar medias con seda de arañas que obsequió a Carlos III, a Catalina de Rusia y al mismísimo Napoleón. También y a pedido de Hervás compuso algunas notas referidas a la lengua mocoví (Furlong, 1938a, pp. 182-184. Page, 2018a, p. 191).

${ }^{49}$ Nevedagnac fue atraído hacia los jesuitas por el cacique Aletín. Era un caudillo de mucha fama, como hombre gran valor que se acercó y estableció en San Javier con 40 familias. Todos fueron adoctrinados y llevados al colegio de los jesuitas de Santa Fe donde recibieron el bautismo por parte del rector, siendo padrinos las personas más distinguidas de la ciudad (Furlong, 1938a, p. 140).

${ }^{50}$ El P. Juan Francisco Ortiz de Ocampo nació en La Rioja el 21 de setiembre de 1729, ingresando a la 
Page. La relación sobre las costumbres y poblados de los mocovíes y abipones tutelados por jesuitas, escrita...

del Colegio del Paraguay para el de Buenos Ayres, por orden del theniente de San ${ }^{\text {ta }}$ Fee de Vera Cruz D $o^{\mathrm{n}}$ Juachin Masiel se le arrestó en el convento de San ${ }^{\text {to }}$ Domingo, y el Herman ${ }^{\circ}$ Miguel Martinez ${ }^{51}$, que para dar cuenta de la Procuraduria de Missiones, que estas tenian en dicha Ciudad, se le havia detenido en el convento de la Merced. El dia ocho caminamos para Buenos Ayres con el nuevo Comissionado N. Piedra Buena, que nos conduxo hasta los Arroyos, y se portó bastante bien. Fué necessario antes de salir de San ${ }^{\text {to }}$ Thomé despachar, y despedirnos de los Indios, que hasta allí nos havian acompañado, y fué necessaria toda diligencia, para que se apartassen de nosotros. Finalmen ${ }^{\text {te }}$ viendo ellos ser precissa esta separacion, postrados á nuestros pies, y echos mares de lagrimas nos suplicaron encarecidamente lostuviessemos presentes en nuestras oraciones, mayormente en el santo sacrificio de la Missa, que jamas los olvidassemos, qie nos acordassemos que eramos sus Padres, á quienes ellos siempre havian amado, y amarian. Por ultimo al desviarse de nosotros nos rogaron, que si en algun tiempo volviessemos á aquellas tierras les avisassemos á nuestro desembarco en Buenos Ayres, para tener ellos los primeros el consuelo de salir á recibir, y abrazar en el camino á sus queridos Padres. Uno entre ellos, y de los mas nobles para demostrar su sentimiento decia: es tan grande, que [24v] que su vehemencia no da lugar á mi passion á desahogarse en lagrimas. Llegados á los Arroyos se volvio el referido comissario N. Piedra Buena, y nos llevó en qualidad de tal hasta Buenos Ayres un N. Benitez, Capitan del partido de los Arroyos sobre dichos, y se huvo con nosotros muy bien. Desde que salimos del Pueblo de $\mathrm{S} a^{\mathrm{n}}$ Xavier hasta que entramos en Buenos Ayres, que fue el dia dos de Octubre no se nos facilitó el decir Missa, ni oirla, ni los dias de fiesta, ni aun en el dia de la Natividad de la Virgen. A la entrada de nuestra carcel en Buenos Ayres, que fué en la casa de exercicios de nuest ${ }^{\text {to }}$ Colegio de Belen, y en el mismo colegio, nos quitaron á todos nuestras frasqueritas, y algunas otras cosas unas por orden del Maior de la Assamblea $\mathrm{D} o^{\mathrm{n}}$ Francisco Gonzalez, que cuidaba de nosotros, bien que no nos abrieron nuestras arcas, que en esto fuimos privilegiados. Aqui estuvimos hasta el diez de Marzo de 1768 en que salimos para la Fragata de Su Magesta ${ }^{\text {d, dicha la Esmeralda }}{ }^{52}$, que estaba en Montevideo. En ella estuvimos á bordo, detenidos en aquel Puerto hasta

Compañía de Jesús del Paraguay en 1748. Era primo de Joaquín Camaño y sobrino del general Francisco Antonio Ortiz de Ocampo. Profesó su cuarto voto en Asunción en 1763, donde era profesor de moral, entre 1762 y 1766 . Fue designado para el colegio de San Ignacio en Buenos Aires y de camino a su nuevo destino fue arrestado, como indica el P. Bustillo, muriendo en Roma el último día de 1816 (Storni, 1980, p. 209).

${ }^{51}$ El coadjutor Juan Miguel Martínez nació en La Puebla de Valverde, Teruel el 23 de marzo de 1710, ingresando a la Compañía de Jesús del Paraguay en 1732, aunque arribó a Buenos Aires dos años después en la expedición del P. Antonio Machoni. Profesó sus últimos votos en Córdoba en el año 1743. La expulsión lo sorprendió en Santa Fe, de donde fue conducido al exilio, falleciendo en Ravena el 31 de octubre de 1788 (Storni, 1980, pp. 175-176).

${ }^{52}$ La fragata "La Esmeralda", a cargo del comandante don Mateo Collado Nieto, recientemente había llegado a Montevideo proveniente de España. Alrededor de 160 jesuitas partieron el 6 de mayo de 1768, arribando al Puerto de Santa María el 22 de agosto. Este viaje a Europa fue relatado en detalle por el P. Paucke, quien nos brinda una detallada relación, señalando entre otras cuestiones que en el viaje murieron los coadjutores, el boliviano Manuel Guzmán y el alemán Tomás Heyrle, que contaba con 70 años y había trabajado de boticario y médico en las misiones por más de 30 años (Page, 2011, p. 65). 
el seis de Mayo, en que nos hicimos á la vela para España, y llegamos á Cadiz el 21 de Agosto del mismo año. Comandaba dicha embarcacion el Capitan de Fragata de la real Armada $\mathrm{D} o^{\mathrm{n}}$ Mattheo del Collado.

Antonio Bustillo

\section{Referencias bibliográficas}

Aguerre Core, F. (2007). Una caída anunciada: el obispo Torre y los jesuitas del Río de la Plata (1757-1773). Montevideo: Linardi y Risso.

Baptista SI, J. (2001). "Paucke (Baucke), Florian. Misionero, escritor, músico”. En: C. E. O’Neill SI \& J. M. Domínguez SI (comp.), Diccionario Histórico de la Compañía de Jesús: biográfico-temático, (T. 4, p. 3.452). Roma: Institutum Historicum.

Dobrizhoffer SJ, M (1967 v.1, 1968 v.2, 1970 v.3). Historia de los abipones. Resistencia: Universidad Nacional del Nordeste, Facultad de Humanidades, Departamento de Historia. Escagedo Salmón, M. (1926). Solares Montañeses. Viejos linajes de la provincia de Santander (Antes Montañas de Burgos). T. 2. Santoña: Tip. Dialco Mnemaen C. P. Dueso.

Furlong SJ, G. (1938a). Entre los mocobíes de Santa Fe, según noticias de los misioneros jesuitas Joaquín Camaño, Manuel Canelas, Francisco Burgés. Román Arto, Antonio Bustillo y Florián Paucke. Buenos Aires: Sebastián Amorrortu e hijos.

Furlong SJ, G. (1938b) Entre los abipones del Chaco, según noticias de los misioneros jesuitas Martín Dobrizhoffer, Domingo Muriel, José Brigniel, Joaquín Camaño, José Joís, Pedro Juan Andreu, José Cardiel y Vicente [Luis] Olcina. Buenos Aires: Talleres San Pablo.

Furlong SJ, G. (1944). Historia del Colegio del Salvador y de sus irradiaciones culturales y espirituales en la ciudad de Buenos Aires 1617-1943, T. I. Buenos Aires: Colegio del Salvador.

Furlong SJ, G. (1953). Pedro Juan Andreu y su Carta a Mateo Andreu, etc. (1750). Buenos Aires: Librería del Plata.

Furlong SJ, G. (1967). Manuel Querini SJ y sus “informes al Rey” (1747-1750. Buenos Aires: Editorial Theoría.

Furlong SJ, G. (1972). Florián Paucke, S.J., y sus cartas al Visitador Contucci (17621764). Buenos Aires: Editorial Casa Pardo.

Galán García, A. (1995). El "Oficio de Indias” de Sevilla y la organización económica y misional de la Compañía de Jesús (1566-1767). Sevilla: Fundación Fondo de Cultura de Sevilla.

Geoghegan, A. R. (1974). "Bibliografía de Guillermo Furlong SJ". Boletín de la Academia Nacional de la Historia, XLVIII, 401-546.

Labougle, R. de (1978). Historia de San Juan de Vera de las Siete Corrientes. (15881814). Buenos Aires: Talleres Graficos Mundial.

Lucaioli, C. P. (2011). "Creatividad, adaptación y resistencia. Ychoalay, un cacique abipón en la frontera austral del Chaco (Siglo XVIII)". Folia Histórica del Nordeste, 19, 91-117. ISBN: 2525-1627. 
Page. La relación sobre las costumbres y poblados de los mocovíes y abipones tutelados por jesuitas, escrita...

Lucaioli, C. P. (2015). "Guerra y persuasión en las fronteras de Santa Fe: La gestión de Francisco Antonio de Vera Mujica (1743-1766)". Memoria Americana, 23, 1, 99 128. ISSN: 1851-3751.

Moriconi, M. (2014). "Intersecciones críticas. Doctrineros en pueblos de indios de Santa Fe después de la expulsión de la Compañía de Jesús (1767-1804)". Revista de ciencias sociales, 26, 29-48. ISBN; 0328-2643.

Page, C. A. (2007). Los viajes de Europa a Buenos Aires, según las crónicas de los jesuitas delos siglos XVII Y XVIII. Córdoba: Báez Ediciones

Page, C. A. (2011). Siete ángeles. Jesuitas en las Reducciones y Colegios de la antigua provincia del Paraguay. Buenos Aires: SB ediciones.

Page, C. A. (2012). Las otras reducciones jesuiticas. Emplazamiento territorial, desarrollo urbano y arquitectónico entre los Siglos XVII y XVIII. Madrid: Editorial Académica Española.

Page, C. A. (2018). "La literatura de los jesuitas expulsos de la Provincia del Paraguay. Memorias de una intensa labor". Cuadernos Dieciochistas, 19, 169-210. ISBN: 1576-7914.

Page, C. A. (2018a). "Martirio y muerte de un jesuita camino a Santa Fe: Santiago Herrero SJ (1717-1747)". Revista de la Junta de Estudios Históricos de Santa $\mathrm{Fe}$, LXXII, 21-51. ISBN: 0326-887X.

Page, C. A. (2019a). El jesuita expulso Lorenzo Casado y su "Relación exacta de la provincia del Paraguay". Córdoba: CIECS-CONICET/UNC y Báez ediciones

Page, C. A. (2019b). "La relación del P Francisco Javier Guevara sobre chiquitos". IHS. Antiguos jesuitas en Iberoamérica, 7, 1, 114-124. ISBN: 2314-3908.

Page, C. A. (2019c). "La ciudad de Corrientes vista por el jesuita expulso P. Francisco Valdés". IHS. Antiguos Jesuitas en Iberoamérica., 7, 1, 125-147. ISBN: 2314-3908.

Pastells SJ, P. y Mateos SJ, F. (1949). Historia de la Compañía de Jesús en la Provincia del Paraguay, VIIIa primera parte 1751-1760. VIIIb Segunda parte 1760-1768. Madrid: Consejo Superior de Investigaciones Científicas.

Paucke SJ, F. (2010). Hacia allá y para acá (memorias). Santa Fe: Ministerio de Innovación y Cultura de la Provincia de Santa Fe.

Piciulo, V. S. (2014). I Gesuiti americani espulsi in Italia e Joaquín Camaño (17671814). Tesis doctoral de la Universitá di Bologna.

Salinas, M. L. y Valenzuela, F. V. (2015). "Los mocobíes del Chaco según la mirada del P. Manuel Canelas SJ”. IHS. Antiguos jesuitas en Iberoamérica, 3, 2, 169-190. ISBN: 2314-3908.

Storni SI, H. (1980). Catálogo de los jesuitas de la Provincia del Paraguay (Cuenca del Plata) 1585-1768. Roma: Institutum Historicum SI.

Storni SI, H. (2001). "Guevara, José. Misionero historiador". En C.E. O’Neill SI \& J. M. Domínguez SI (comp.), Diccionario Histórico de la Compañía de Jesús: biográfico-temático, $(2,1.837)$. Roma: Institutum Historicum. 